OPEN ACCESS

Edited by:

Vito Di Noto,

University of Padova, Italy

Reviewed by:

Pramod K. Kalambate,

Huazhong University of Science and

Technology, China

Man-Jiang Xie

Fourth Military Medical University,

China

Marta De Zotti,

University of Padova, Italy

*Correspondence:

Sheng-Nan Wu

snwu@mail.ncku.edu.tw

Specialty section:

This article was submitted to

Electrochemistry,

a section of the journal

Frontiers in Chemistry

Received: 21 February 2019

Accepted: 25 July 2019

Published: 22 August 2019

Citation:

Huang M-H, Liu P-Y and WU S-N (2019) Characterization of Perturbing

Actions by Verteporfin, a Benzoporphyrin Photosensitizer, on Membrane lonic Currents.

Front. Chem. 7:566

doi: 10.3389/fchem.2019.00566

\section{Characterization of Perturbing Actions by Verteporfin, a Benzoporphyrin Photosensitizer, on Membrane lonic Currents}

\author{
Mei-Han Huang ${ }^{1}$, Ping-Yen Liu ${ }^{2}$ and Sheng-Nan Wu ${ }^{3,4 *}$ \\ ${ }^{1}$ College of Medical and Health Sciences, Fooyin University, Kaohsiung City, Taiwan, ${ }^{2}$ Division of Cardiovascular Medicine, \\ National Cheng Kung University Medical College, Tainan City, Taiwan, ${ }^{3}$ Institute of Basic Medical Sciences, National Cheng \\ Kung University Medical College, Tainan City, Taiwan, ${ }^{4}$ Department of Physiology, National Cheng Kung University Medical \\ College, Tainan City, Taiwan
}

Verteporfin (VP), a benzoporphyrin derivative, has been clinically tailored as a photosensitizer and recently known to suppress YAP-TEAD complex accompanied by suppression of the growth in an array of neoplastic cells. However, the detailed information is little available regarding possible modifications of it and its related compounds on transmembrane ionic currents, despite its growing use in clinical settings. In this study, from whole cell recordings, VP $(0.3-100 \mu \mathrm{M})$ increased the amplitude of $\mathrm{Ca}^{2+}$-activated $\mathrm{K}^{+}$currents $\left(I_{\mathrm{K}(\mathrm{Ca})}\right)$ in pituitary tumor $\left(\mathrm{GH}_{3}\right)$ cells in a concentration-dependent manner with an $\mathrm{EC}_{50}$ value of $2.4 \mu \mathrm{M}$. VP-stimulated $I_{\mathrm{K}(\mathrm{Ca})}$ in these cells was suppressed by further addition of either paxilline, iberiotoxin, or dithiothreitol, but not by that of tobultamide or TRAM-39. VP at a concentration of $10 \mu \mathrm{M}$ mildly suppressed the amplitude of delayed-rectifier $\mathrm{K}^{+}$current; however, it had minimal effects on $\mathrm{M}$-type $\mathrm{K}^{+}$current. In cell-attached current recordings, addition of $V P$ to the recording medium enhanced the activity of large-conductance $\mathrm{Ca}^{2+}$-activated $\mathrm{K}^{+}\left(\mathrm{BK}_{\mathrm{Ca}}\right)$ channels. In the presence of VP, additional illumination with light intensity of $5.5 \mathrm{~mW} / \mathrm{cm}^{2}$ raised the probability of $\mathrm{BK}_{\mathrm{Ca}}$-channel openings further. Addition of VP decreased the peak amplitude of L-type $\mathrm{Ca}^{2+}$ current together with slowed inactivation time course of the current; however, it failed to modify voltage-gated $\mathrm{Na}^{+}$current. Illumination of $\mathrm{GH}_{3}$ cells in continued presence of VP also induced a non-selective cation current. Additionally, VP increased the activity of $\mathrm{BK}_{\mathrm{Ca}}$ channels in human 13-06-MG glioma cells with an $\mathrm{EC}_{50}$ value of $1.9 \mu \mathrm{M}$. Therefore, the effects of VP on ionic currents described herein tend to be upstream of its inhibition of YAP-TEAD complex and they are conceivably likely to contribute to the underlying mechanisms through which it and its structurally similar compounds effect the modifications in functional activities of pituitary or glial neoplastic cells, if the in vivo findings occur.

Keywords: verteporfin, $\mathrm{Ca}^{2+}$-activated $\mathrm{K}^{+}$current, $\mathrm{K}^{+}$current, $\mathrm{BKCa}$ channel, $\mathrm{Ca}^{2+}$ current, pituitary tumor cell, glioma cell 


\section{INTRODUCTION}

Verteporfin (VP, Visudyne $\left.{ }^{\circledR}\right)$, a benzoporphyrin derivative, is a compound therapeutically tailored as a photosensitizer for photodynamic therapy, because this agent can effectively eliminate aberrant blood vessels in the eye associated with conditions such as either the wet form of macular degeneration or abnormal choroidal neovascularizations (Schmidt-Erfurth and Hasan, 2000; DeRosa and Crutchley, 2002; Renno et al., 2004; Rosenblatt et al., 2005; Hua et al., 2014; Hu et al., 2015; Chen and $\mathrm{Hu}, 2017$; Ghazai et al., 2017; Konstantinou et al., 2017; AlAmri et al., 2018; Baskaran et al., 2018; Liu et al., 2018; Min et al., 2018; Iacono et al., 2019; Isildak et al., 2019).

Yes-associated protein (YAP) has been reported to be a main mediator of the Hippo pathway, which is thought to promote cancer development (Feng et al., 2016; Gibault et al., 2016; Kandoussi et al., 2017; Abe et al., 2018; Chen et al., 2019). A number of recent reports has demonstrated that VP can suppress the aberrant growth in a variety of tumor cell lines, including breast cancer, glioma, ovarian cancer, hepatocellular carcinoma, and retinoblastoma, through an intriguing mechanism linked to specific suppression of YAP-TEAD complex (Valero et al., 2015; Feng et al., 2016; Al-Moujahed et al., 2017; Gibault et al., 2017; Abe et al., 2018; Mulder et al., 2018; Li et al., 2019; Pellosi et al., 2019; Qin et al., 2019; Zhang et al., 2019). This compound has been indeed long supposed to be an inhibitor of YAP-TEAD complex and hence to play the roles in growth inhibition in different types of neoplastic cells including pituitary tumors and gliomas (Feng et al., 2016; Gibault et al., 2016, 2017; Al-Moujahed et al., 2017; Deng et al., 2018; Eales et al., 2018; Liao et al., 2018; Pellosi et al., 2019; Zhang et al., 2019).

The photodynamic therapy with different photosensitizers such as hypericin or VP has been previously demonstrated to be effective in the treatment of different types of hyper- or neoplastic tissues, including the residual small tumor in pituitary gland (Faustino et al., 1997; Marks et al., 2000; Valenzeno and Tarr, 2001; DeRosa and Crutchley, 2002; Rahimipour et al., 2003; Brown et al., 2004; Renno et al., 2004; Solban et al., 2006; Triesscheijn et al., 2006; Zhou et al., 2006; Cole et al., 2008; Tekrony et al., 2011; Nemes et al., 2016; Deng et al., 2018). Previous work indeed reported the capability of photosensitizers (e.g., rose bengal) to modify membrane ionic current in pituitary tumor $\left(\mathrm{GH}_{3}\right)$ cells or heart cells (Tarr et al., 1994; Valenzeno and Tarr, 1998, 2001). Alternatively, earlier reports have also revealed that VP could induce anterior ischemic optic neuropathy in rodents (Karacorlu et al., 2004; Min et al., 2018). However, surprisingly, little information has been thus far available concerning any possible modifications of

\footnotetext{
Abbreviations: $\mathrm{BK}_{\mathrm{Ca}}$ channel, large-conductance $\mathrm{Ca}^{2+}$-activated $\mathrm{K}^{+}$channel; $\mathrm{EC}_{50}$, the concentration required for half-maximal stimulation; GMQ, 2guanidine-4-methylquinazoline; $I$ - $V$, current vs. voltage; $I_{\mathrm{Ca}, \mathrm{L}}, \mathrm{L}-$ type $\mathrm{Ca}^{2+}$ current; $\mathrm{IK}_{\mathrm{Ca}}$ channel, intermediate-conductance $\mathrm{Ca}^{2+}$-activated $\mathrm{K}^{+}$channel; $I_{\mathrm{K}(\mathrm{Ca})}, \mathrm{Ca}^{2+}$-activated $\mathrm{K}^{+}$current; $I_{\mathrm{K}(\mathrm{DR})}$, delayed-rectifier $\mathrm{K}^{+}$current; $I_{\mathrm{K}(\mathrm{M})}, \mathrm{M}$ type $\mathrm{K}^{+}$current; $I_{\mathrm{Na}}$, voltage-gated $\mathrm{Na}^{+}$current; $I_{\mathrm{NS}}$, non-selective cation current; TEA, tetraethylammonium chloride; TEAD, TEA domain transcription factor; $\tau_{\text {inact(s) }}$, slow component of inactivation time constant for ionic current; TTX, tetrodotoxin; VP, verteporfin (Visudyne ${ }^{\circledR}$ ); YAP, yes-associated protein.
}

VP on the level of surface membrane including ionic channels in a variety of neoplastic cells, despite its clinical approval for photodynamic therapy.

Because of the considerations described above, we sought to determine whether VP and its related compounds could exert any possible perturbations on different types of ionic currents which include $\mathrm{Ca}^{2+}$-activated $\mathrm{K}^{+}$current $\left(I_{\mathrm{K}(\mathrm{Ca})}\right)$, delayed-rectifier $\mathrm{K}^{+}$ current $\left(I_{\mathrm{K}(\mathrm{DR})}\right)$, M-type $\mathrm{K}^{+}$current $\left(I_{\mathrm{K}(\mathrm{M})}\right)$, large-conductance $\mathrm{Ca}^{2+}$-activated $\mathrm{K}^{+}\left(\mathrm{BK}_{\mathrm{Ca}}\right)$ channel, L-type $\mathrm{Ca}^{2+}$ current $\left(I_{\mathrm{Ca}, \mathrm{L}}\right)$, and voltage-gated $\mathrm{Na}^{+}$current $\left(I_{\mathrm{Na}}\right)$. In this study, we provide substantial evidence to unravel that VP is indeed capable of modifying membrane ionic currents in pituitary tumor $\left(\mathrm{GH}_{3}\right)$ cells and in glioma (13-06-MG) cells, the actions of which are apparently of clinical relevance and appear to be upstream of its inhibition at YAC-TEAD complex.

\section{MATERIALS AND METHODS}

\section{Drugs and Solutions}

Verteporfin (VP, Visudyne ${ }^{\circledR}, \quad$ BPD-MA, CL-318,952, $\mathrm{C}_{41} \mathrm{H}_{42} \mathrm{~N}_{4} \mathrm{O}_{8}$,), rose bengal, tetraethylammonium chloride (TEA), tetrodotoxin (TTX), and tolbutamide were acquired from Sigma-Aldrich (St. Louis, MO), iberiotoxin and paxilline from Alomone (Jerusalem, Israel), and A-803467 (5-(4-chlorophenyl)$\mathrm{N}$-(3,5-dimethoxyphenyl)-2-furancarboxamide), A-887826 (5-(4-butoxy-3-chlorophenyl)-N-[[2-(4-morpholinyl)-3pyridinyl]methyl-3-pyridine carboxamide), 2-guanidine-4methylquinazoline (GMQ), S(-)-Bay K 8644 (Bay K 8644), nifedipine, NS1619, PF573228 (3,4-dihydro-6-[[4-[[[3(methylsulfonyl)phenyl]methyl]amino]-5-(trifluoromethyl)-

2-pyrimidinyl]amino]-2(1H)-quinolinone) and TRAM-39 (2-cholo- $\alpha, \alpha$-diphenylbenzeneacetonitrile) were from Tocris Cookson Ltd. (Bristol, UK), and pioglitazone was obtained from Takeda (Tokyo, Japan). Chlorotoxin was kindly provided by Professor Dr. Woei-Jer Chuang, Department of Biochemistry, National Cheng Kung University Medical College, Tainan, Taiwan. To protect VP from light, stock solution containing this compound was wrapped in aluminum foil. Cell culture media were obtained from Invitrogen (Carlsbad, CA), unless stated otherwise, and other chemicals or solvents such as $\mathrm{CdCl}_{2}$, $\mathrm{CsCl}, \mathrm{CsOH}$, and $\mathrm{N}$-methyl-D-glucamine ${ }^{+}\left(\mathrm{NMDG}^{+}\right)$were of analytical reagent grade. The twice-distilled water that had been de-ionized through a Millipore-Q system was used in all experiments.

The composition of bath solution (i.e., HEPES-buffered normal Tyrode's solution) for $\mathrm{GH}_{3}$ or 13-06-MG cells was as follows (in $\mathrm{mM}$ ): $\mathrm{NaCl} 136.5, \mathrm{KCl} 5.4, \mathrm{CaCl}_{2} 1.8, \mathrm{MgCl}_{2} 0.53$, glucose 5.5, and HEPES-NaOH buffer 5.5 ( $\mathrm{pH} 7.4$ ). To measure

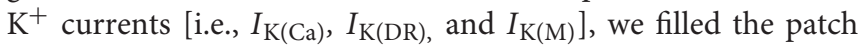
pipette with a solution (in $\mathrm{mM}$ ): $\mathrm{KCl} 140, \mathrm{MgCl}_{2} 1, \mathrm{Na}_{2} \mathrm{ATP}$ 3, $\mathrm{Na}_{2}$ GTP 0.1, EGTA 0.1, and HEPES-KOH buffer 5 ( $\mathrm{pH} \mathrm{7.2);}$ however, in some separate set of experiments of reducing the level of intracellular $\mathrm{Ca}^{2+}$, EGTA concentration in the solution was changed to $10 \mathrm{mM}$. To record $I_{\mathrm{K}(\mathrm{M})}$, high $\mathrm{K}^{+}$-bathing solution was composed of the following (in $\mathrm{mM}$ ): $\mathrm{KCl} 145, \mathrm{MgCl}_{2} 0.53$, and HEPES-KOH 5 ( $\mathrm{pH}$ 7.4). In order to measure $I_{\mathrm{Na}}, I_{\mathrm{Ca}, \mathrm{L}}$, or $I_{\mathrm{NS}}$ precisely, we replaced $\mathrm{K}^{+}$ions inside the pipette solution with 
equimolar $\mathrm{Cs}^{+}$ions, and $\mathrm{pH}$ was then appropriately adjusted to 7.2 with $\mathrm{CsOH}$. In order to fully suppress $\mathrm{Na}^{+}, \mathrm{Ca}^{2+}$ or $\mathrm{K}^{+}$currents, TTX $(1 \mu \mathrm{M}), \mathrm{CdCl}_{2}(0.5 \mathrm{mM})$ or TEA $(10 \mathrm{mM})$ was added to the recording medium, respectively. The pipette solution and culture medium were commonly filtered on the day of use with Acrodisc ${ }^{\circledR}$ syringe filter with $0.2 \mu \mathrm{m}$ Supor ${ }^{\circledR}$ membrane (Pall Corp., Port Washington, NY).

\section{Cell Culture}

$\mathrm{GH}_{3}$ pituitary tumor cells, obtained from the Bioresources Collection and Research Center ([BCRC-60015]; Hsinchu, Taiwan), were maintained in Ham's F-12 media supplemented with $15 \%$ horse serum $(\mathrm{v} / \mathrm{v}), 2.5 \%$ fetal calf serum $(\mathrm{v} / \mathrm{v})$, and $2 \mathrm{mM}$ L-glutamine (Wu et al., 2003; Lin et al., 2014; So et al., 2018). The glioblastoma multiforme cell line (13-06-MG) was kindly provided by Professor Dr. Carol A. Kruse, Department of Neurosurgery, Ronald Reagan UCLA Medical Center, LA, CA, USA. Cells were grown in high-glucose (4 g/l) Dulbecco's modified Eagle media supplemented with $10 \%$ heat-inactivated fetal bovine serum (Huang et al., 2015). $\mathrm{GH}_{3}$ or 13-06-MG cells were maintained at $37^{\circ} \mathrm{C}$ in a humidified environment of $5 \% \mathrm{CO}_{2} / 95 \%$ air and sub-cultured weekly and fresh media were generally added every 2-3 days to maintain a healthy cell population. Glial cells were verified by identifying glial fibrillary acidic protein, a cytoskeletal protein. The experiments were performed after 5 or 6 days of subcultivation (60$80 \%$ confluence).

\section{Electrophysiological Measurements}

Shortly before experimentation, we dissociated the cells and then placed a few drops of cell suspension onto a custom-built recording chamber affixed on the stage of a DM-IL inverted microscope (Leica, Wetzlar, Germany). As being settled down the bottom of the chamber, cells were bathed at a room temperature of $20-25^{\circ} \mathrm{C}$ in normal Tyrode's solution, the composition of which is describe above. Once cells were placed in the VPcontaining medium, the recordings were carried out under very dim room light. For illumination system, we focused visible light onto a spot on the recording chamber which covered completely the area of cells exposed to VP in the central region with an illumination intensity of $\sim 5.5 \mathrm{~mW} / \mathrm{cm}^{2}$. We fabricated the recording pipette from Kimax-51 capillary tubes (\#34500; Kimble, Vineland, NJ) using a vertical PP-83 (Narishige, Tokyo, Japan) or a horizontal P-97 Flaming/Brown (Sutter, Novato, CA) puller, and their tips were fire-polished with an MF-83 microforge (Narishige). During the measurements, the pipette with a resistance of 3-5 M $\Omega$, which was inserted into holder, was gently maneuvered by using a WR-98 micromanipulator (Narishige). Patch-clamp experiments were measured in either cell-attached, inside-out, or whole-cell arrangement by using an RK-400 patch-clamp amplifier (Bio-Logic, Claix, France) connected with a personal computer with 64-bit processor (Lin et al., 2004; Wu et al., 2017; So et al., 2019). Shortly before giga-seal formation was achieved, the potentials were appropriately corrected for the liquid junction potential that commonly develop at the pipette tip as the composition of the pipette solution was quite different from that in the bath. Tested compounds were applied by perfusion or added to the bath to obtain the final concentration indicated.

\section{Data Recordings}

The data comprising both potential and current traces were stored online in an ASUS VivoBook Flip-14 touchscreen laptop computer (TP412U; Taipei City, Taiwan) at $10 \mathrm{kHz}$ equipped with the 12-bit Digidata 1440A interface (Molecular Devices, Inc., Sunnyvale, CA). The latter device was used for efficient analog-to-digital/digital-to-analog conversion. During the experiments, data acquisition system was electronically driven by pCLAMP 10.7 software (Molecular Devices) run under Windows 10 (Redmond, WA), and the signals were simultaneously monitored on LCD monitor (MB169B+; ASUS, Taipei, Taiwan) through a USB type-C connection. Current signals were low-pass filtered at $2 \mathrm{kHz}$ with FL-4 four-pole Bessel filter (Dagan, Minneapolis, MN) to minimize background noise. Through digital-to-analog conversion, the pCLAMP-generated voltage-clamp profiles with different waveforms were applied to determine the current-voltage $(I-V)$ relationships for different

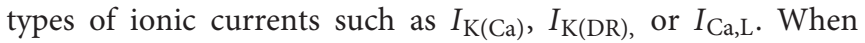
high-frequency stimuli used to elicit the cells were required, an Astro-med Grass S88X dual output pulse stimulator (Grass Technologies, West Warwick, RI) was used.

\section{Data Analyses}

To evaluate concentration-dependent effect of VP on the stimulation of $I_{\mathrm{K}(\mathrm{Ca})}$ in $\mathrm{GH}_{3}$ cells, each cell was depolarized to $+50 \mathrm{mV}$ from a holding potential of $0 \mathrm{mV}$. Current amplitude measured at the end of each depolarizing pulse during cell exposure to $100 \mu \mathrm{M}$ VP was taken to be $100 \%$, and those in the presence of different VP concentrations were then compared. To determine concentration-dependent stimulation of $\mathrm{VP}$ on $\mathrm{BK}_{\mathrm{Ca}}$ channels recorded from human 13-06-MG glioma cells, channel activity at $+60 \mathrm{mV}$ relative to the bath during the exposure to $100 \mu \mathrm{M}$ VP was considered as $100 \%$, and the channel open probabilities at different VP concentrations were compared. The mean values for concentration-dependent relation of VP on the stimulation of $I_{\mathrm{K}(\mathrm{Ca})}$ or $\mathrm{BK}_{\mathrm{Ca}}$ channels were least-squares fitted to a modified Hill function. That is,

$$
\text { Percentage increase }(\%)=\frac{E_{\max }}{1+\frac{E C_{50}^{n_{H}}}{[V P]^{n_{H}}}},
$$

where [VP] is the VP concentration applied, $\mathrm{EC}_{50}$ the concentration required for half-maximal stimulation of $I_{\mathrm{K}(\mathrm{Ca})}$ or $\mathrm{BK}_{\mathrm{Ca}}$ channels, $\mathrm{n}_{\mathrm{H}}$ the Hill coefficient, and $E_{\max }$ VP-induced maximal stimulation of either $I_{\mathrm{K}(\mathrm{Ca})}$ in $\mathrm{GH}_{3}$ cells or $\mathrm{BK} \mathrm{Ca}$ channels in 13-06-MG cells.

Single-BK $\mathrm{Ca}$ channel currents were analyzed by pClamp 10.7 software (Molecular Devices). Multi-gaussian adjustments of the amplitude distributions among channels were commonly used to determine single-channel currents. Functional independence between channels was verified by comparing the observed stationary probabilities with the values calculated according to the binomial law. The open-state probability of the channels 
was expressed as $N \cdot P_{\mathrm{O}}$ which can be estimated using the following equation:

$$
N \cdot P_{O}=\frac{A_{1}+2 A_{2}+3 A_{3}+\ldots+n A_{n}}{A_{0}+A_{1}+A_{2}+A_{3}+\ldots+A_{n}},
$$

where $N$ is the number of active channels in the patch examined, $A_{0}$ the area under the curve of an all-points histogram corresponding to the closed state, and $A_{1}-A_{\mathrm{n}}$ are the histogram areas reflecting the levels of distinct open state for 1 to $\mathrm{n}$ channels in the patch.

\section{Statistical Analyses}

To perform linear or non-linear (e.g., sigmoidal or exponential function) curve fitting to the data set (i.e., the goodness of fit) was appropriately utilized by using OriginPro (OriginLab, Northampton, MA) or Prism version 5.0 (GraphPad, La Jolla, $\mathrm{CA})$. Data were analyzed and are plotted using OriginPro (OriginLab), and they were expressed as mean \pm standard error of the mean (SEM). The paired or unpaired Student's $t$-test, or oneway analysis of variance (ANOVA) followed by post-hoc Fisher's least-significance difference test for multiple comparisons, were implemented for the statistical evaluation of differences among means. We further used non-parametric Kruskal-Wallis test, as the assumption of normality underlying ANOVA was likely to be violated. Statistical analyses were commonly performed by using IBM SPSS ${ }^{\circledR}$ version 20.0 (IBM Corp., Armonk, NY). $P<0.05$ was considered significant, unless stated otherwise.

\section{RESULTS}

\section{Stimulatory Effect of VP on $\mathrm{Ca}^{2+}$-Activated $\mathrm{K}^{+}\left(\mathrm{I}_{\mathrm{K}(\mathrm{Ca})}\right)$ Measured From Pituitary Tumor $\left(\mathrm{GH}_{3}\right)$ Cells}

The whole cell configuration of the patch-clamp technique was initially carried out to evaluate any possible perturbations of VP on $I_{\mathrm{K}(\mathrm{Ca})}$ amplitude in these cells. In the experiments designed to measure $I_{\mathrm{K}(\mathrm{Ca})}$, we immersed the cells in normal Tyrode's solution containing $1.8 \mathrm{mM} \mathrm{CaCl}_{2}$, and the recording pipette was filled with a solution which contained a low concentration $140 \mathrm{mM} \mathrm{K}^{+}, 0.1 \mathrm{mM}$ EGTA, and $3 \mathrm{mM}$ ATP. As whole-cell mode was achieved, the examined cell was maintained at the level of $0 \mathrm{mV}$ to inactivate other types of voltage-gated $\mathrm{K}^{+}$currents which are enriched in these cells (Stojilkovic et al., 2010; So et al., 2018), and ionic currents in response to a series of the voltage pulses between 0 and $+60 \mathrm{mV}$ were robustly elicited. Current amplitude was progressively increased as the test voltage became more positive (Figure 1). When extracellular $\mathrm{Ca}^{2+}$ was removed, current amplitudes were greatly reduced; meanwhile, an increase in intracellular EGTA concentration from 0.1 to $10 \mathrm{mM}$ also abolished these currents. This type of outward currents with an outwardly rectifying property has been hence regarded as $I_{\mathrm{K}(\mathrm{Ca})}$ (Lin et al., 2004; Wu et al., 2017), the amplitudes of which become greatly small as intracellular $\mathrm{Ca}^{2+}$ level is decreased (i.e., intracellular EGTA with $10 \mathrm{mM}$ ).

As cells were exposed to VP, the amplitude of $I_{\mathrm{K}(\mathrm{Ca})}$ in response to depolarizing step was considerably increased
(Figures 1A,B). For example, VP at a concentration of $3 \mu \mathrm{M}$ significantly raised $I_{\mathrm{K}(\mathrm{Ca})}$ measured at the level of $+50 \mathrm{mV}$ from $184 \pm 13$ to $257 \pm 24 \mathrm{pA}(n=11, P<0.05)$. Washout of VP, current amplitude returned to $197 \pm 14 \mathrm{pA}(n=10, P<0.05)$. Similarly, as cells were exposed to $10 \mu \mathrm{M}$ NS1619, an activator of $\mathrm{BK}_{\mathrm{Ca}}$ channels, $I_{\mathrm{K}(\mathrm{Ca})}$ amplitude at $+50 \mathrm{mV}$ increased from $179 \pm 14$ to $235 \pm 25 \mathrm{pA}(n=8, P<0.05)$. Figure $1 \mathrm{~B}$ illustrates the averaged current-voltage $(I-V)$ relationships of $I_{\mathrm{K}(\mathrm{Ca})}$ with or without addition of VP $(3 \mu \mathrm{M})$.

Concentration-dependent stimulation of $I_{\mathrm{K}(\mathrm{Ca})}$ on $\mathrm{GH}_{3}$ cells by VP was further derived and then constructed. In these experiments, we bathed the cells in normal Tyrode's solution, the examined cell was clamped at $0 \mathrm{mV}$, and depolarizing pulse from 0 to $+50 \mathrm{mV}$ was then delivered. As illustrated in Figures 2A,B, the presence of different VP concentrations $(0.1-100 \mu \mathrm{M})$ could be efficacious at raising $I_{\mathrm{K}(\mathrm{Ca})}$ amplitude in a concentrationdependent manner. According to least-squares minimization procedure, the half-maximal concentration required for the stimulatory effect of VP on $I_{\mathrm{K}(\mathrm{Ca})}$ amplitude was estimated to be $2.4 \mu \mathrm{M}$, and it at a concentration of $100 \mu \mathrm{M}$ fully increased current amplitude elicited by voltage depolarization. The experimental results thus demonstrate that VP has a stimulatory action on $I_{\mathrm{K}(\mathrm{Ca})}$ seen in $\mathrm{GH}_{3}$ cells in a concentrationdependent manner.

\section{Comparison of Effects of VP, VP Plus Tolbutamide, VP Plus TRAM-39, VP Plus Paxilline, VP Plus Iberiotoxin, and VP Plus Dithiothreitol on $\mathrm{I}_{\mathrm{K}(\mathrm{Ca})}$ Amplitude in $\mathrm{GH}_{3}$ Cells}

An earlier work has demonstrated that VP might disrupt mitochondrial inner membrane potential in cancer cells (Belzacq et al., 2001). On the other hand, the activity of different types of $\mathrm{K}^{+}$channels present in pituitary cells including $\mathrm{GH}_{3}$ cells (Stojilkovic et al., 2010) might contribute synergistically to VP-mediated effect on $I_{\mathrm{K}(\mathrm{Ca})}$. Therefore, during cell exposure to VP, subsequent addition of different compounds including tolbutamide, TRAM-39, paxilline, iberiotoxin, and dithiothreitol was further studied to evaluate whether those agents exert any modulation on $I_{\mathrm{K}(\mathrm{Ca})}$ stimulated by VP. As depicted in Figure 2C, subsequent application of neither tolbutamide nor TRAM-39 could attenuate VP-mediated increase of $I_{\mathrm{K}(\mathrm{Ca})}$ amplitude; however, that of paxilline, iberiotoxin, or dithiothreitol did reduce $I_{\mathrm{K}(\mathrm{Ca})}$ raised by VP. Tolbutamide and TRAM-39 are blockers of ATP-sensitive $\mathrm{K}^{+}\left(\mathrm{K}_{\mathrm{ATP}}\right)$ and intermediated-conductance $\mathrm{Ca}^{2+}$-activated $\mathrm{K}^{+}\left(\mathrm{IK}_{\mathrm{Ca}}\right)$ channels (Chen P. C. et al., 2018; Chen T. S. et al., 2018; Liu et al., 2019a), respectively, while paxilline and iberiotoxin could suppress the activity of large-conductance $\mathrm{Ca}^{2+}$-activated $\mathrm{K}^{+}$ $\left(\mathrm{BK}_{\mathrm{Ca}}\right)$ channels, respectively. Dithiothreitol is recognized as a sulfhydryl reducing agent.

\section{Inhibitory Effect of VP on Delayed-Rectifier $\mathrm{K}^{+}$Current $\left(\mathrm{I}_{\mathrm{K}(\mathrm{DR})}\right)$ in $\mathrm{GH}_{3}$ Cells}

We further studied whether, in addition to $I_{\mathrm{K}(\mathrm{Ca})}$, another different types of $\mathrm{K}^{+}$currents [e.g., $I_{\mathrm{K}(\mathrm{DR})}$ ] could be modified by 

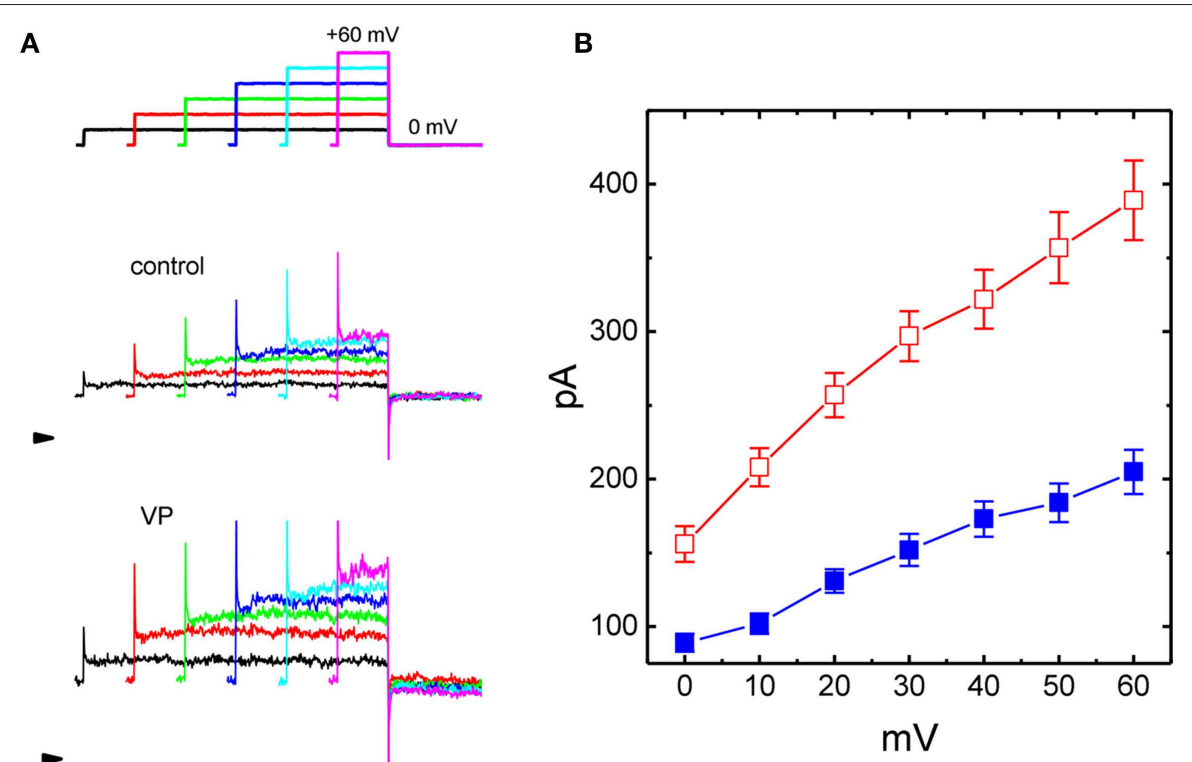

FIGURE 1 | Effects of verteporfin (VP) on $\mathrm{Ca}^{2+}$-activated $\mathrm{K}^{+}$current $\left(\mathrm{I}_{\mathrm{K}(\mathrm{Ca})}\right)$ measured from pituitary $\mathrm{GH}_{3}$ cells. In these experiments, cells were bathed in normal Tyrode's solution containing $1.8 \mathrm{mM} \mathrm{CaCl}_{2}$, and the recording pipette was filled with $\mathrm{K}^{+}$-containing solution. The examined cell was voltage clamped at $0 \mathrm{mV}$ to inactivate most of other types of voltage-gated $\mathrm{K}^{+}$currents, and a series of the voltage steps ranging between 0 and $+60 \mathrm{mV}$ [indicated in the uppermost part of $(\mathbf{A})$ ] was delivered. (A) Representative $I_{\mathrm{K}(\mathrm{Ca})}$ traces taken in the absence (upper) and presence (lower) of $3 \mu \mathrm{M}$ VP. The arrowhead indicates the zero current level, and calibration bar in the bottom right corner refers to both panels. (B) Averaged current-voltage $(I-V)$ relationships of $I_{\mathrm{K}(\mathrm{Ca})}$ measured from the control $(\mathbf{\square})$ and during cell exposure to $3 \mu \mathrm{M}$ VP $(\square)$ (mean \pm SEM; $n=11$ for each point).

the presence of VP. In these experiments, cells were bathed in $\mathrm{Ca}^{2+}$-free Tyrode's solution containing $1 \mu \mathrm{M}$ TTX and $0.5 \mathrm{mM}$ $\mathrm{CdCl}_{2}$ and we filled the recording pipette by using $\mathrm{K}^{+}$-containing solution. Addition of $3 \mu \mathrm{M}$ VP was not found to modify $I_{\mathrm{K}(\mathrm{DR})}$ amplitude significantly. However, as $\mathrm{GH}_{3}$ cells were exposed to $10 \mu \mathrm{M} \mathrm{VP}$, the $I_{\mathrm{K}(\mathrm{DR})}$ amplitudes elicited in response to stepwise depolarizing voltages were progressively decreased (Figures 3A,B). Figure 3B illustrates averaged $I-V$ relationships of $I_{\mathrm{K}(\mathrm{DR})}$ measured at the end of each depolarizing pulse, as the results were obtained in the absence and presence of $10 \mu \mathrm{M} \mathrm{VP}$. For example, as the examined cells were depolarized from -50 to $+40 \mathrm{mV}$, addition of $10 \mu \mathrm{M}$ VP diminished $I_{\mathrm{K}(\mathrm{DR})}$ amplitude from $1,382 \pm 145$ to $1,114 \pm 138 \mathrm{pA}(n=13, P<0.05)$. After washout of the drug, current amplitude returned to $1,328 \pm$ $141 \mathrm{pA}(n=11, P<0.05)$. However, no modification of $I_{\mathrm{K}(\mathrm{DR})}$ inactivation time course in response to membrane depolarization was demonstrated in the presence of $10 \mu \mathrm{M}$ VP. Therefore, these results showed that $\mathrm{VP}$ at a concentration of $10 \mu \mathrm{M}$ mildly suppressed the amplitude of $I_{\mathrm{K}(\mathrm{DR})}$ in $\mathrm{GH}_{3}$ cells.

\section{Failure of VP to Modify M-Type $\mathrm{K}^{+}$Current (IK(M)) Recorded From $\mathrm{GH}_{3}$ Cells}

In addition to $I_{\mathrm{K}(\mathrm{DR})}$, another type of $\mathrm{K}^{+}$current [i.e., $I_{\mathrm{K}(\mathrm{M})}$ ] detected in $\mathrm{GH}_{3}$ cells (Sankaranarayanan and Simasko, 1996; Stojilkovic et al., 2010; So et al., 2019) was further designed to evaluate whether the presence of VP has any modifications on this type of $\mathrm{K}^{+}$current. To amplify $I_{\mathrm{K}(\mathrm{M})}$, we bathed cells in high$\mathrm{K}^{+}(145 \mathrm{mM}), \mathrm{Ca}^{2+}$-free solution, the composition of which is described in Materials and Methods. In these experiments, the examined cell held in voltage clamp at $-50 \mathrm{mV}$ with a long-duration depolarizing step to $-10 \mathrm{mV}$ was able to generate a slowly activating $\mathrm{K}^{+}$inward current followed by a largely deactivating current, namely $I_{\mathrm{K}(\mathrm{M})}$, as described previously (Sankaranarayanan and Simasko, 1996; Chen T. S. et al., 2018; Liu et al., 2019b; So et al., 2019). As illustrated in Figure 4, under our experimental conditions, we were unable to find out that the presence of $10 \mu \mathrm{M}$ VP had any measurable effect on $I_{\mathrm{K}(\mathrm{M})}$ amplitude [141 $\pm 19 \mathrm{pA}$ [in the control] vs. $140 \pm 18 \mathrm{pA}$ [in the absence of $10 \mu \mathrm{M} \mathrm{VP]}, n=11, P>0.05]$. However, in continued presence of $10 \mu \mathrm{M} \mathrm{VP}$, further application of $3 \mu \mathrm{M}$ pioglitazone was effective at suppressing $I_{\mathrm{K}(\mathrm{M})}$, as evidenced by the results showing that, in continued presence of $10 \mu \mathrm{M} \mathrm{VP}$, further application of $10 \mu \mathrm{M}$ pioglitazone substantially decreased $I_{\mathrm{K}(\mathrm{M})}$ amplitude to $78 \pm 12 \mathrm{pA}(n=11, P<0.05)$. Therefore, the data prompted us to indicate that distinguishable from $I_{\mathrm{K}(\mathrm{Ca})}$ or $I_{\mathrm{K}(\mathrm{DR})}$, the $I_{\mathrm{K}(\mathrm{M})}$ observed in $\mathrm{GH}_{3}$ cells was relatively resistant to modification by VP, though it was potently suppressed by pioglitazone (Chen T. S. et al., 2018).

\section{Effects of VP on the Activity of $\mathrm{Bk}_{\mathrm{ca}}$ Channels in $\mathrm{GH}_{3}$ Cells}

The results from our whole-cell experiments reflected that $I_{\mathrm{K}(\mathrm{Ca})}$ described above could be $\mathrm{K}^{+}$flux through the largeconductance subtype of $\mathrm{K}_{\mathrm{Ca}}$ channels, because VP-induced increase in $I_{\mathrm{K}(\mathrm{Ca})}$ was effectively suppressed by iberiotoxin or paxilline, yet not by TRAM-39. Therefore, in attempts to ascertain how VP interacts pertinently with ion-channel activity to modify $I_{\mathrm{K}(\mathrm{Ca})}$, the effects of $\mathrm{VP}$ on $\mathrm{BK}_{\mathrm{Ca}}$-channel activity was 

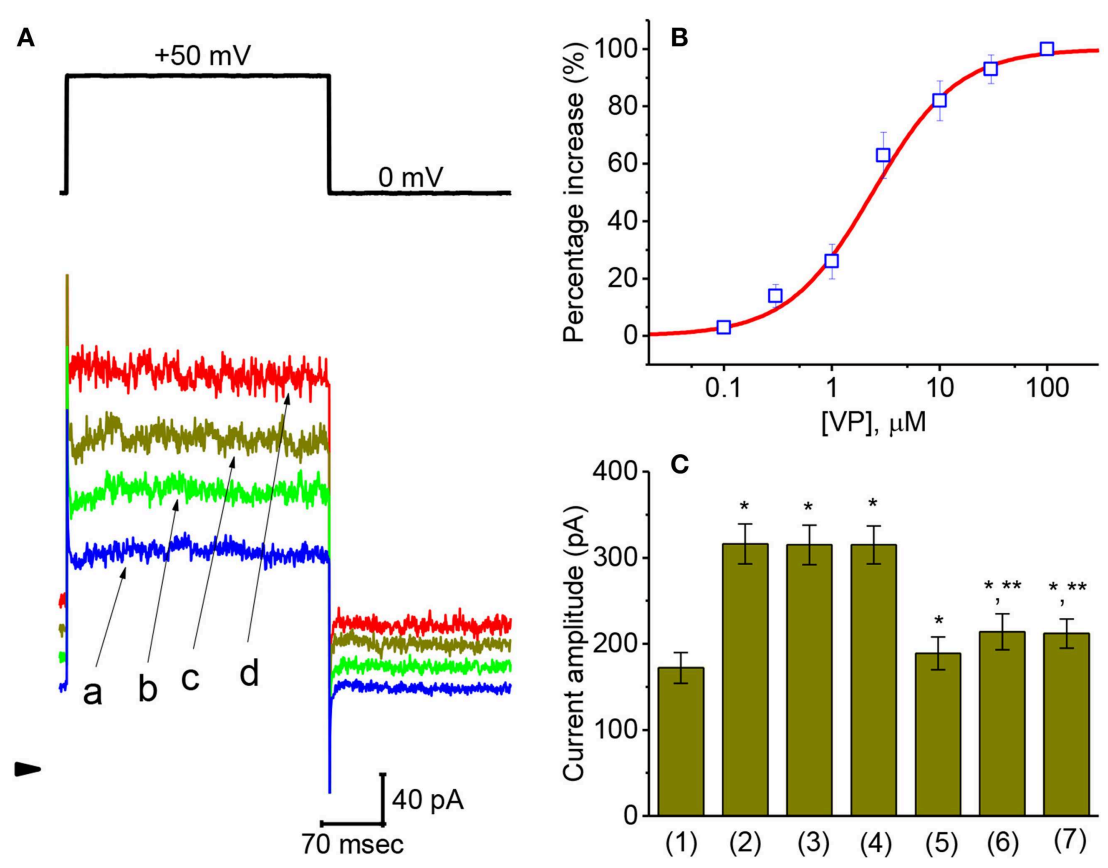

FIGURE 2 | Concentration-dependent effect of VP on $/ \mathrm{K}(\mathrm{Ca})$ and the effects of different related compounds on VP-stimulated $/ \mathrm{K}(\mathrm{Ca})$ in $\mathrm{GH} / 3$ cells. The experiments were conducted in cells bathed in normal Tyrode's solution and the depolarizing pulse from 0 to $+50 \mathrm{mV}$ [indicated in the upper part of (A)] was delivered to the cell examined. (A) Superimposed $I_{\mathrm{K}(\mathrm{Ca})}$ taken during step depolarization. a: control; b:1 $1 \mathrm{M}$ VP; c: $3 \mu \mathrm{M}$ VP; d: $10 \mu \mathrm{M}$ VP. Arrowhead is the zero-current level and calibration bar refers to all traces. (B) Concentration-dependent effect of VP on $/_{K}(\mathrm{Ca})$ amplitude [mean $\pm \mathrm{SEM} ; n=10-14$ for each point ( $\square$ )]. The examined cell was depolarized from 0 to $+50 \mathrm{mV}$ and current amplitude at the end of each depolarizing step was measured. As cells were exposed to $100 \mu \mathrm{M}$ VP, $I_{\mathrm{K}(\mathrm{Ca})}$ amplitude was taken to be $100 \%$, and those at different VP concentrations were then compared. The values for $\mathrm{EC}_{50}$ and the Hill coefficient were $2.4 \mu \mathrm{M}$ and 1.1, respectively. Non-linear smooth line was least-squares fitted to a modified Hill function described in Materials and Methods. (C) Summary bar graph showing the effect of VP, VP plus tolbutamide, VP plus TRAM-39, VP plus paxilline, VP plus iberiotoxin, and VP plus dithiothreitol. Each bar showing / $/ \mathrm{K}(\mathrm{Ca})$ amplitude at the level of $+60 \mathrm{mV}$ indicates the mean \pm SEM $(n=11-14)$. ${ }^{*}$ Significantly different from control $(P<0.05)$ and ${ }^{* *}$ significantly different from VP $(3 \mu \mathrm{M})$ alone group $(P<0.05)$.

also investigated in cell-attached or inside-out configuration. In cell-attached current recordings, cells were bathed in normal Tyrode's solution containing $1.8 \mathrm{mM} \mathrm{CaCl}_{2}$, the activity of $\mathrm{BK}_{\mathrm{Ca}}$ channels measured at $+60 \mathrm{mV}$ relative to the bath can be readily detected in these cells. In particular, when VP $(3 \mu \mathrm{M})$ was applied to the bath medium, the probability of channel openness was drastically raised (Figures 5A,B). The open probability of $\mathrm{BK}_{\mathrm{Ca}}$ channels maintained at $+60 \mathrm{mV}$ in the control was found to be $0.014 \pm 0.004(n=13)$. One minute after addition of VP $(3 \mu \mathrm{M})$ to the bath, the channel open probability was significantly increased to $0.024 \pm 0.007$ ( $n=13, P<0.05)$. The channel activity was reduced to $0.018 \pm 0.005(n=12)$ after washout of the agent. However, the amplitude of single-channel currents remained unaltered in the presence of VP. The single-channel conductance of $\mathrm{BK}_{\mathrm{Ca}}$ channels in control cells was $146 \pm 8 \mathrm{pS}(n=12)$, a value that did not differ significantly from that $(147 \pm 13 \mathrm{pS}, n$ $=12, P>0.05)$ obtained in the presence of $\operatorname{VP}(3 \mu \mathrm{M})$. Moreover, in continued presence of $3 \mu \mathrm{M}$ VP, further exposure to illumination with light intensity of $5.5 \mathrm{~mW} / \mathrm{cm}^{2}$ increased channel open probability further to $0.047 \pm 0.011(n=11, P$ $<0.01$ ). Subsequent addition of $1 \mu \mathrm{M}$ paxilline reduced channel activity significantly (Figure 5B), as evidenced by a significant reduction in the channel open probability to $0.017 \pm 0.005$ ( $n$ $=11, P<0.05)$.

\section{Effect of VP, VP Plus GMQ, and VP PF573228 on $\mathrm{BK}_{\mathrm{Ca}}$-Channel Activity in $\mathrm{GH}_{3}$ Cells}

We also evaluated whether VP could exert any perturbation on $\mathrm{BK}_{\mathrm{Ca}}$ channels in inside-out patch of the cell. Cells were immersed in high $\mathrm{K}^{+}$solution containing $1 \mu \mathrm{M} \mathrm{Ca}^{2+}$, and the experiments were conducted in inside-out current recordings. As shown in Figure 6, when the excised patch was maintained at $+60 \mathrm{mV}$, the addition of $3 \mu \mathrm{M}$ VP to the intracellular leaflet of the inside-out patch did not modify the channel open probability. However, in continued presence of VP, further addition of either 2-guanidine-4-methylquinazoline (GMQ; $3 \mu \mathrm{M}$ ) or PF573228 $(3 \mu \mathrm{M})$ was effective at raising the probability of $\mathrm{BK}_{\mathrm{Ca}}$ channels. GMQ or PF573228 was previously reported to activate $\mathrm{BK}_{\mathrm{Ca}}$ channels (So et al., 2011, 2018). The results thus showed the inability of VP to alter the probability of $\mathrm{BK}_{\mathrm{Ca}}$-channel openings recorded from the excised patch of $\mathrm{GH}_{3}$ cells.

\section{Suppressive Effect of VP on L-Type $\mathrm{Ca}^{2+}$ Current $\left(\mathrm{I}_{\mathrm{Ca}, \mathrm{L}}\right)$ in $\mathrm{GH}_{3}$ Cells}

Whether VP exerts any perturbations on voltage-gated $I_{\mathrm{Ca}, \mathrm{L}}$ in these cells was further studied, because any modifications in $I_{\mathrm{Ca}, \mathrm{L}}$ magnitude can modify the level of intracellular $\mathrm{Ca}^{2+}$, thereby influencing either the activity of $\mathrm{BK}_{\mathrm{Ca}}$ channels or 


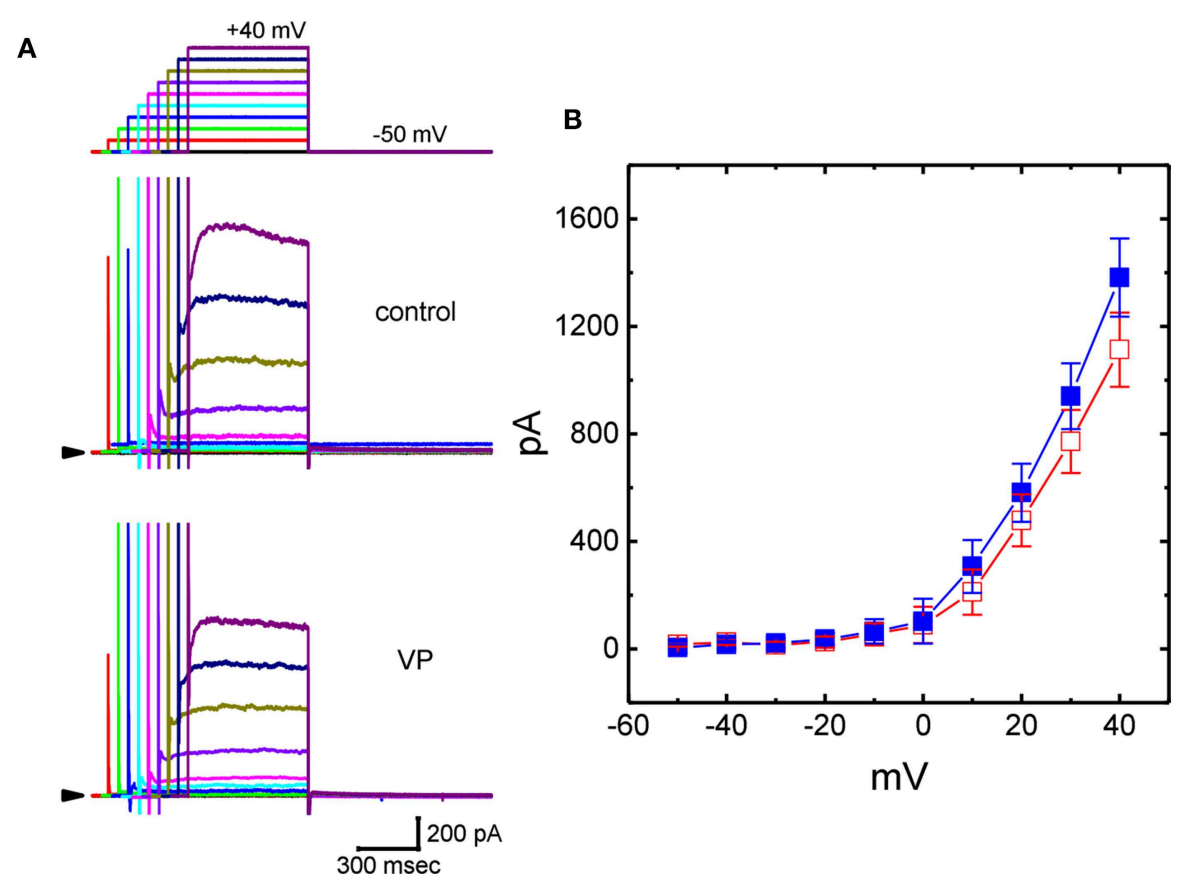

FIGURE 3 | Effects of VP on delayed-rectifier $\mathrm{K}^{+}$current $\left(I_{\mathrm{K}(\mathrm{DR})}\right)$ in $\mathrm{GH}_{3}$ cells. In these experiments, we bathed cells in Ca ${ }^{2+}$-free Tyrode's solution containing $1 \mu \mathrm{M}$ tetrodotoxin (TTX), and whole-cell currents were recorded by filling the pipette with $\mathrm{K}^{+}$-containing solution. The examined cell was held at $-50 \mathrm{mV}$ and a series of depolarizing steps ranging between -50 and $+40 \mathrm{mV}$ was applied [indicated in the uppermost part of (A)]. (A) Superimposed /K(DR) traces obtained during the control (upper) and cell exposure to $10 \mu \mathrm{M}$ VP (lower). Arrowhead in each panel represents the zero-current level. (B) Averaged I-V relationships for $/ \mathrm{K}$ (DR) obtained with or without the addition of $10 \mu \mathrm{M}$ VP (mean \pm SEM; $n=13$ for each point). Current amplitudes were measured at the end of each depolarizing step. $\mathbf{\square}$ : control; $\square$ : in the presence of $10 \mu \mathrm{M}$ VP.

$I_{\mathrm{K}(\mathrm{Ca})}$ amplitude (Wu et al., 1998a,b, 2003; Stojilkovic et al., 2010). As cells were exposed to different VP concentrations the peak amplitude of $I_{\mathrm{Ca}, \mathrm{L}}$ elicited in response to single depolarizing step was progressively decreased (Figures 7A,B). The peak amplitude of $I_{\mathrm{Ca}, \mathrm{L}}$ by membrane depolarization was suppressed by nifedipine $(3 \mu \mathrm{M})$ and enhanced by Bay K 8644 $(3 \mu \mathrm{M})$ (data not shown). Moreover, the addition of $3 \mu \mathrm{M} \mathrm{VP}$ suppressed the peak amplitude of $I_{\mathrm{Ca}, \mathrm{L}}$ from $426 \pm 22$ to $267 \pm 14 \mathrm{pA}(n=12, P<0.05)$. Concomitant with this, the inactivation time constant of $I_{\mathrm{Ca}, \mathrm{L}}$ became slowed (Figure 7C). The value for the slow component of $I_{\mathrm{Ca}, \mathrm{L}}$ inactivation time constant $\left(\tau_{\text {inact(s) }}\right)$ was prolonged to $63.7 \pm 7.2 \mathrm{~ms}$ from a control value of $30.9 \pm 5.6 \mathrm{~ms}(n=12, P<0.05)$. However, the fast component for the inactivation time constant of $I_{\mathrm{Ca}, \mathrm{L}}$ did not differ significantly between the absence and presence of $3 \mu \mathrm{M}$ VP. The results indicate that the presence of VP is capable of altering the amplitude and inactivation time course of $I_{\mathrm{Ca}, \mathrm{L}}$ elicited in response to rapid membrane depolarization.

\section{Stimulatory Effect of VP on Non-selective Cation Current $\left(\mathbf{I}_{\mathrm{NS}}\right)$ in $\mathrm{GH}_{3}$ Cells}

In another set of experiments, we tested whether VP has any effects on $I_{\mathrm{NS}}$. The results showed that addition of VP $(3 \mu \mathrm{M})$ did not have any effect on ion currents measured at the level of $-50 \mathrm{mV}$. However, in continued presence of $\mathrm{VP}$, as light illumination with intensity of $5.5 \mathrm{~mW} / \mathrm{cm}^{2}$ was further applied, an inward current was progressively induced as the examined cell was voltage-clamp held at the level of $-50 \mathrm{mV}$ (Figure 7D). Similar findings were observed in eight different $\mathrm{GH}_{3}$ cells examined. As bathing solution was replaced with $\mathrm{NMDG}^{+}$solution, this current could still be induced in the presence of VP plus light exposure. However, chlorotoxin $(1 \mu \mathrm{M})$, an inhibitor of $\mathrm{Cl}^{-}$channels, did not have any effects on photosensitized VP-induced inward currents. Therefore, consistent with previous observations reported from frog heart cells (Tarr et al., 1994), the inward currents seen in these cells exhibited to be the non-selective, yet not $\mathrm{Cl}^{-}$ion-specific, nature of the ionic conductance.

\section{Inability of VP to Modify Voltage-Gated $\mathrm{Na}^{+}$ Current $\left(\mathrm{I}_{\mathrm{Na}}\right)$}

Another important type of voltage-gated ionic current (i.e., $I_{\mathrm{Na}}$ ) was also further examined to evaluate the possible modification of VP on this inward current. However, we were unable to detect any measurable change in the amplitude or gating of $I_{\mathrm{Na}}$ elicited by brief step depolarization (Figure 8). For example, the maximal peak amplitude of $I_{\mathrm{Na}}$ in the control was $2.52 \pm 0.17 \mathrm{nA}(n=$ 12 ), a value which did not differ significantly from that during cell exposure to $3 \mu \mathrm{M}$ VP [2.52 $\pm 0.18 \mathrm{nA}[n=12, P>0.05]$ ] In continued presence of $3 \mu \mathrm{M}$ VP, subsequent addition of either A-803467 $(3 \mu \mathrm{M})$ or A-887826 $(3 \mu \mathrm{M})$ was potent in suppressing the peak $I_{\mathrm{Na}}$ in $\mathrm{GH}_{3}$ cells (Figure 8); however, no modification 
A

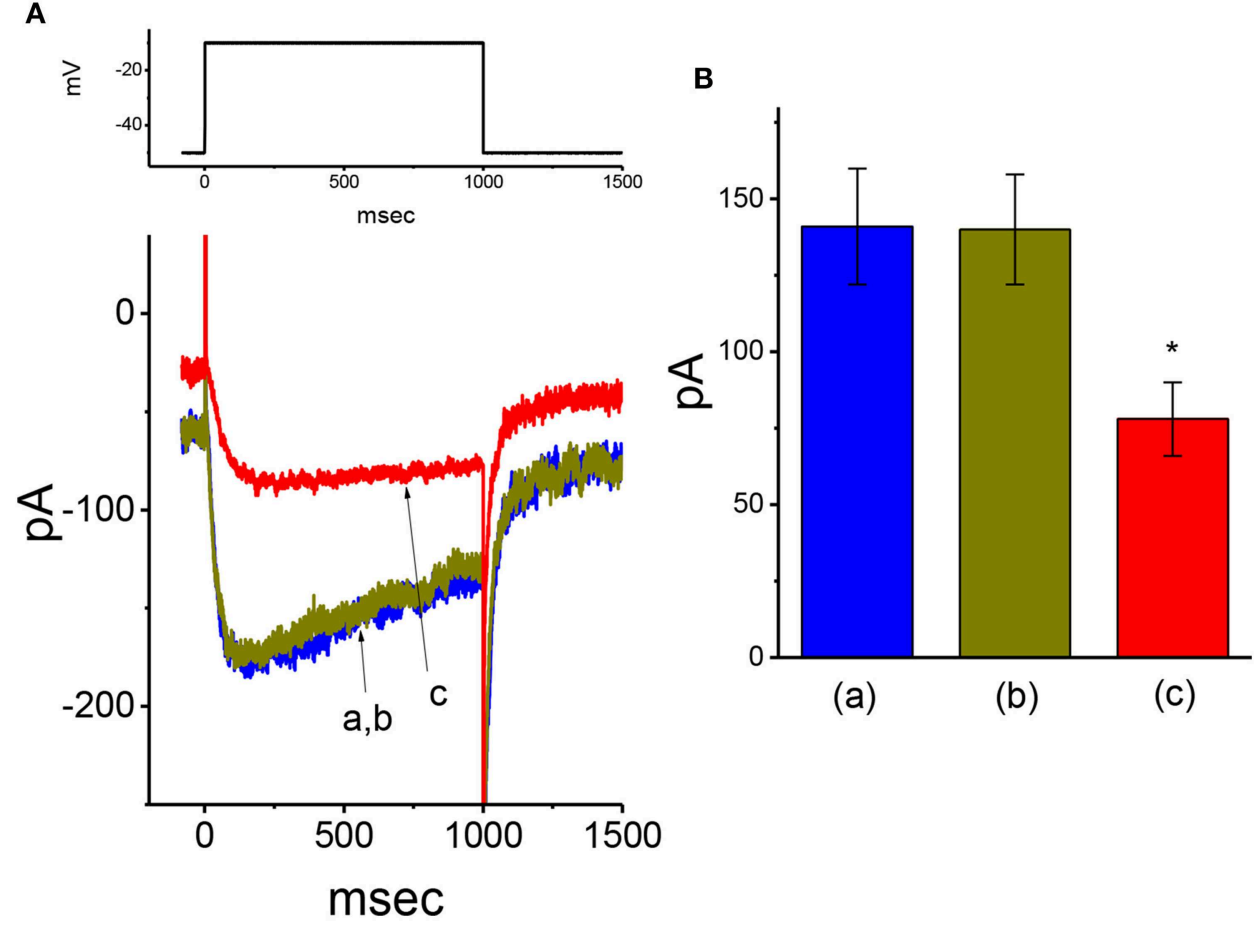

FIGURE 4 | Failure of VP to alter M-type $\mathrm{K}^{+}$current $\left(I_{\mathrm{K}(\mathrm{M})}\right)$ recorded from $\mathrm{GH}_{3}$ cells. In these experiments, we bathed cells in high- $\mathrm{K}^{+}$, Ca ${ }^{2+}$-free solution, and filled the pipette by using $\mathrm{K}^{+}$-containing solution. (A) Original $/_{\mathrm{K}(\mathrm{M})}$ traces in response to long-lasting membrane depolarization from -50 to $-10 \mathrm{mV}$. a: control; b: $10 \mu \mathrm{M}$ VP; c: $10 \mu \mathrm{M}$ VP plus $3 \mu \mathrm{M}$ pioglitazone. The voltage protocol used is indicated in the upper part. (B) Summary bar graph showing the effect of VP and VP plus pioglitazone on $/_{\mathrm{K}(\mathrm{M})}$ elicited by membrane depolarization (mean $\pm \mathrm{SEM} ; n=11$ for each bar). ${ }^{*}$ Significantly different from control $(P<0.05)$.

in $I_{\mathrm{Na}}$ inactivation in the presence of these two agents was demonstrated. A-803467 or A-887826 was previously reported to inhibit $\mathrm{Na}_{\mathrm{V}} 1.8$-encoded currents potently (Rush and Cummins, 2007; Zhang et al., 2010).

\section{Effect of VP on $\mathrm{Bk}_{\mathrm{ca}}$-Channel Activity in Human 13-06-MG Glioma Cells}

VP has been recently reported to inhibit the proliferation of glioma cells (Al-Moujahed et al., 2017; Eales et al., 2018; Pellosi et al., 2019). In a final series of experiments, we therefore intended to investigate whether the presence of VP is also able to modulate ionic currents in another types of neoplastic cells (e.g., malignant glioma cells). As depicted in Figures 9A,B, in cell-attached measurements, the activity of $\mathrm{BK}_{\mathrm{Ca}}$ channels in 1306-MG glioma cells was robustly detected as described previously (Huang et al., 2015; Liu et al., 2015). Moreover, addition of VP to the bath increased the probability of $\mathrm{BK}_{\mathrm{Ca}}$-channel openings in these cells. For example, as the cells were maintained at $+60 \mathrm{mV}$ relative to the bath, the exposure to $3 \mu \mathrm{M} \mathrm{VP}$ significantly elevated the channel open probability from $0.018 \pm 0.007$ to $0.038 \pm 0.011(n=12, P<0.05)$. Therefore, similar to that of $\mathrm{GH}_{3}$ cells described above, $\mathrm{BK}_{\mathrm{Ca}}$-channel activity existing in 13-06-MG cells was indeed found to be sensitive to stimulation by VP. Apart from the inhibition of YAP-TEAD complex, VPinduced inhibition of cell proliferation in glioma (Eskelin et al.,
2008; Eales et al., 2018) could, to some extent, be linked to its stimulatory action on $\mathrm{BK}_{\mathrm{Ca}}$-channel activity.

\section{DISCUSSION}

The present investigation discloses important findings that VP produced a stimulatory effect on $\mathrm{Ca}^{2+}$-activated $\mathrm{K}^{+}$current $\left(I_{\mathrm{K}(\mathrm{Ca})}\right)$ in pituitary $\mathrm{GH}_{3}$ cells; however, it mildly depressed $I_{\mathrm{K}(\mathrm{DR})}$ amplitude with no modification on $I_{\mathrm{Na}}$ or $I_{\mathrm{K}(\mathrm{M})}$. The stimulatory effect on $I_{\mathrm{K}(\mathrm{Ca})}$ caused by VP was presumably related to changes in the level of intracellular $\mathrm{Ca}^{2+}$ concentrations. The results showing that removal of extracellular $\mathrm{Ca}^{2+}$ suppressed VP-induced increase in $I_{\mathrm{K}(\mathrm{Ca})}$ also suggest that extracellular $\mathrm{Ca}^{2+}$ and internal $\mathrm{Ca}^{2+}$ release both contribute to the increase in the amplitude of $I_{\mathrm{K}(\mathrm{Ca})}$ in these cells.

The $\mathrm{EC}_{50}$ value for either VP-induced stimulation of $I_{\mathrm{K}(\mathrm{Ca})}$ observed either in pituitary $\mathrm{GH}_{3}$ cells or increase in $\mathrm{BK}_{\mathrm{Ca}}$ channel activity in 13-06-MG glioma cells was estimated to be 2.4 or $1.9 \mu \mathrm{M}$, respectively. These values are quite close to those that are either therapeutically achievable or required for the inhibitory actions on YAP-TEAD complex in different types of neoplastic cells (Faustino et al., 1997; Zhou et al., 2006; Feng et al., 2016; Gibault et al., 2016, 2017; Chen and $\mathrm{Hu}, 2017)$. As VP stimulated the $I_{\mathrm{K}(\mathrm{Ca})}$ amplitude within a few minutes in $\mathrm{GH}_{3}$ cells, it is therefore reasonable to elaborate that there is a conceivable link between the 
A
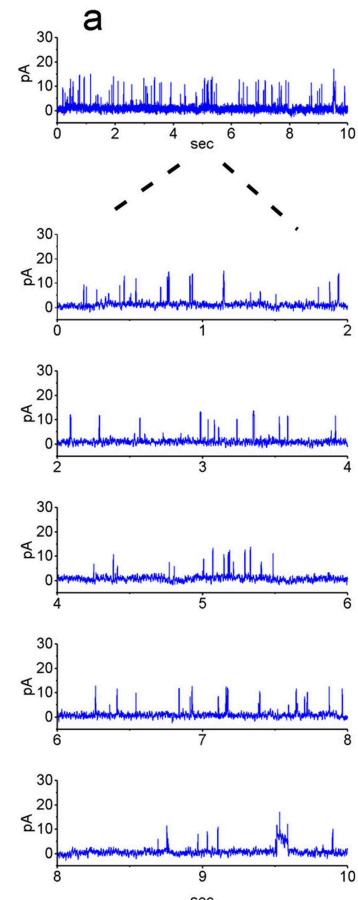
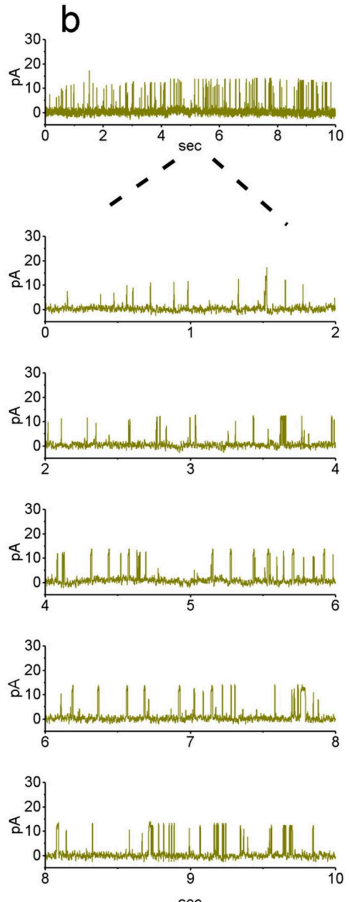
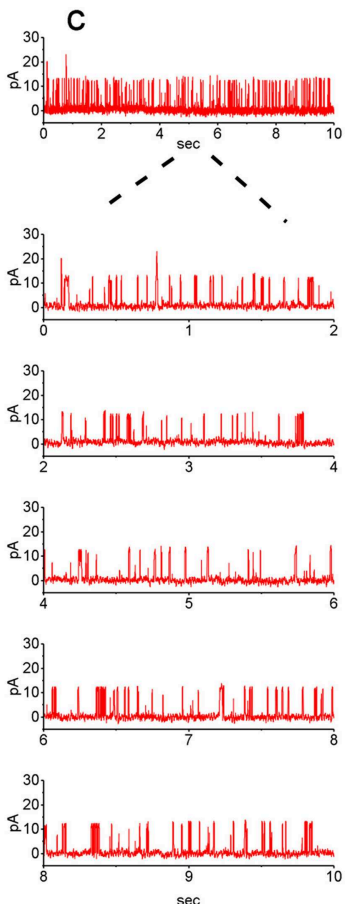

B

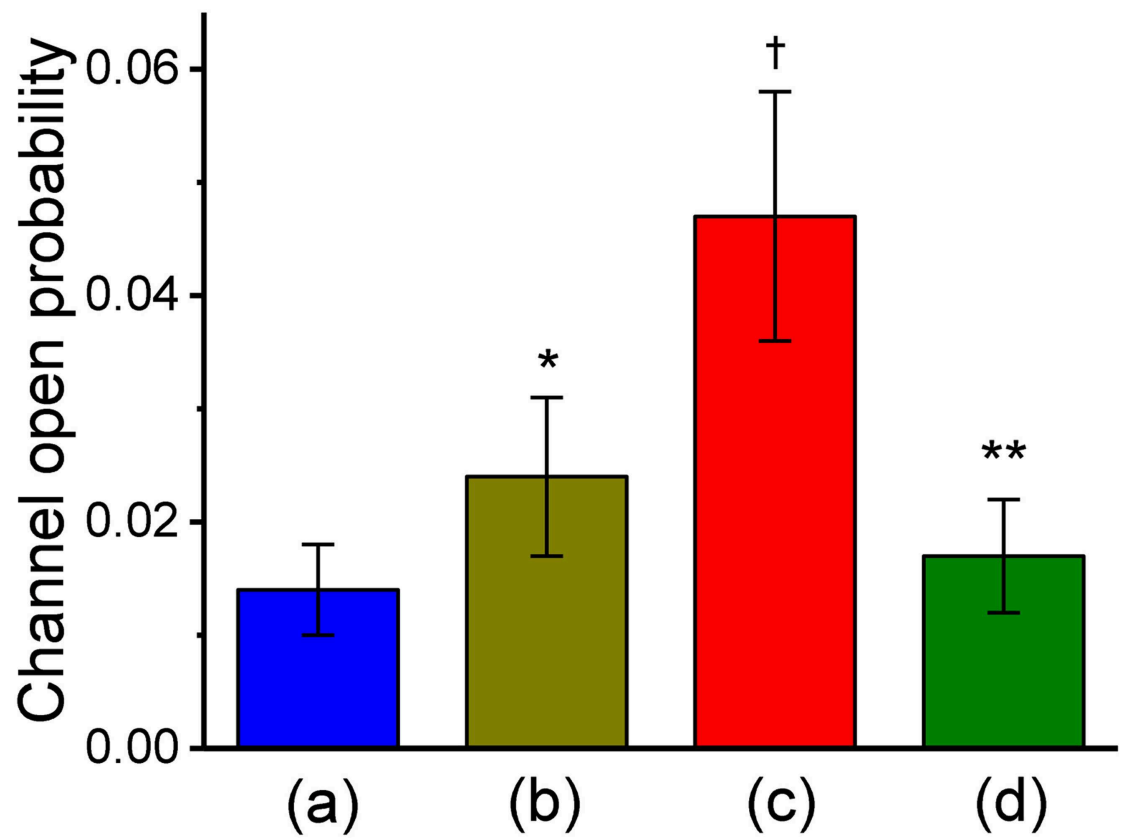

FIGURE 5 | Stimulatory effect of VP on the activity of large-conductance $\mathrm{Ca}^{2+}$-activated $\mathrm{K}^{+}\left(\mathrm{BK}_{\mathrm{Ca}}\right)$ channels measured from on-cell patch recordings of $\mathrm{GH}_{3}$ cells. In these cell-attached current recordings, cells were bathed in normal Tyrode's solution containing $1.8 \mathrm{mM} \mathrm{CaCl}_{2}$ and channel activity was measured by filling the pipette with $\mathrm{K}^{+}$-containing solution. (A) $\mathrm{BK}_{\mathrm{Ca}}$ channel activity measured at the holding potential of $+60 \mathrm{mV}$ relative to the bath. Panel a is control (i.e., in the absence of light and photosensitizer VP), while panels $b$ and $c$ were obtained in the presence of $3 \mu \mathrm{MVP}$ and $3 \mu \mathrm{VP}$ plus illumination with a light intensity of $5.5 \mathrm{~mW} / \mathrm{cm}^{2}$, respectively. The lower parts in each panel indicate the expanded traces recorded from the uppermost part. Note that channel opening causes an upward defection. (B) Summary bar graph showing the effects of VP and VP plus illumination on the probability of $\mathrm{BK}_{\mathrm{Ca}}$ channels that would be open (mean $\pm \mathrm{SEM}$; $n=11-13$ for each bar). ${ }^{*}$ Significantly different from control $(P<0.05)$, ${ }^{~}$ significantly different from control $(P<0.01)$, and ${ }^{* *}$ significantly different from VP $(3 \mu \mathrm{M})$ plus illumination group $(P<0.01)$ 

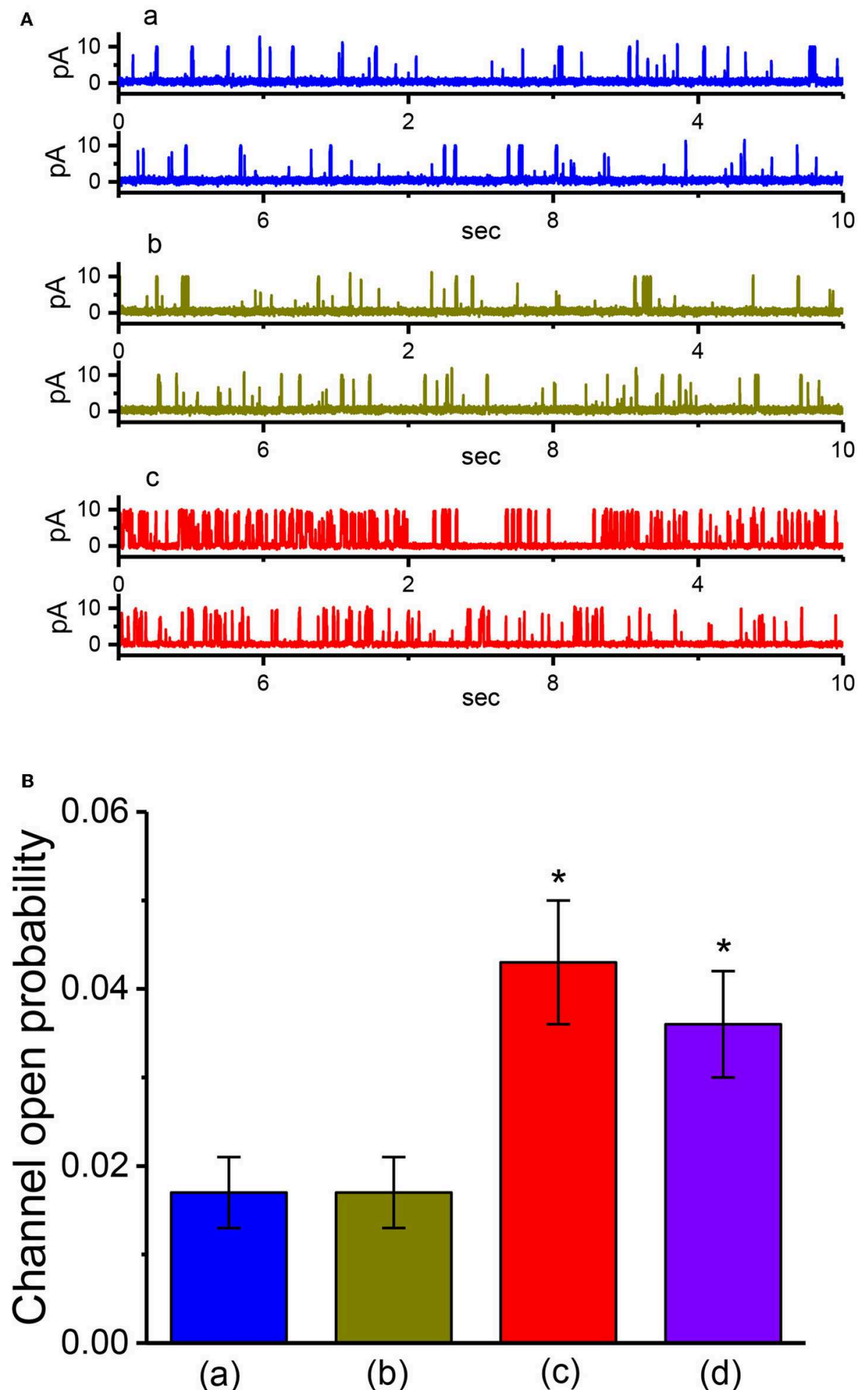

FIGURE 6 | The activity of $\mathrm{BK}_{\mathrm{Ca}}$ channels produced by VP, VP plus GMQ, or VP plus PF573228 under inside-out current recordings. In these experiments, cells were bathed in high- $\mathrm{K}^{+}$solution which contained $1 \mu \mathrm{M} \mathrm{Ca}^{2+}$, the excised patch was maintained at $+60 \mathrm{mV}$, and tested compound was applied to the bath. (A) $\mathrm{BK}_{\mathrm{Ca}}$-channel current traces measured at $+60 \mathrm{mV}$. a: control; b: $3 \mu \mathrm{M} \mathrm{VP;} \mathrm{c:} 3 \mu \mathrm{M}$ VP plus $3 \mu \mathrm{M} \mathrm{GMQ}$. The open state of the channel is indicated by upward deflection. (B) Summary bar graph showing the effects of VP, VP plus GMQ, or VP plus PF573228 on the probability of BK $\mathrm{Ca}_{\text {a }}$ channels that would be open (mean \pm $\mathrm{SEM} ; n=12$ for each bar). *Significantly different from control (i.e., in the absence of any agents; $P<0.05)$ and ${ }^{* *}$ significantly different from $\mathrm{VP}(3 \mu \mathrm{M})$ alone group $(P<0.05)$. 
A

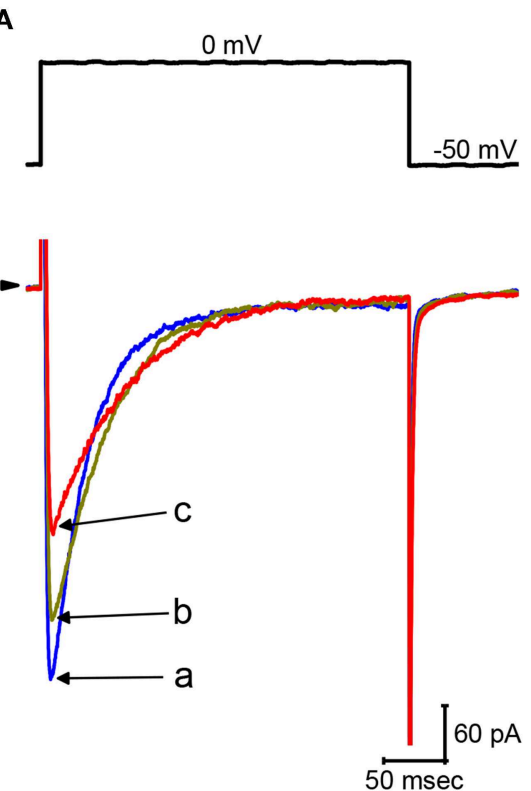

$50 \mathrm{msec}$
B

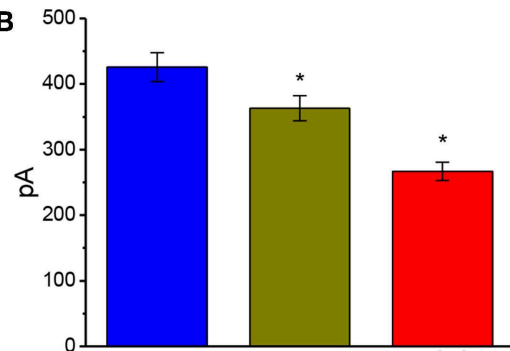

(a)

(b)

(c)

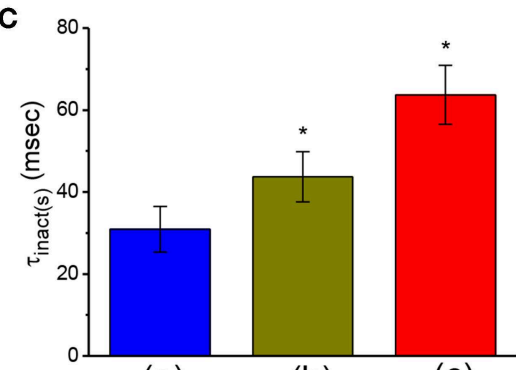

(a)

(b)

(c)

D

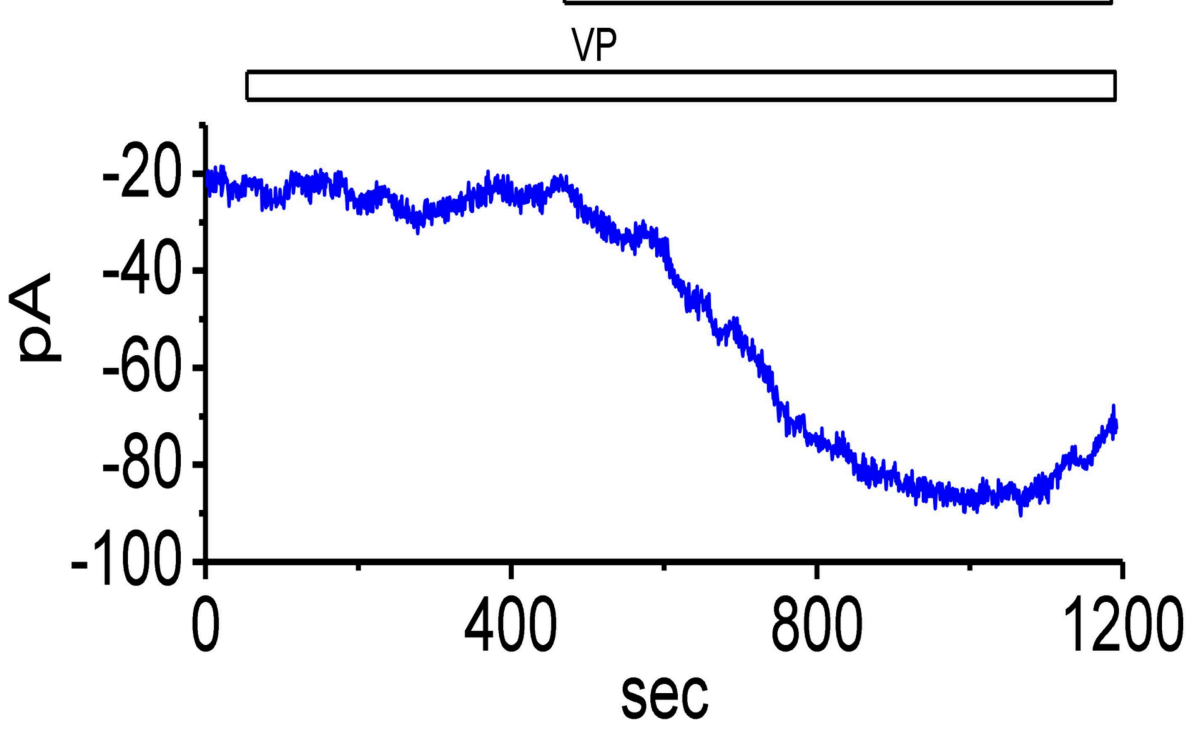

FIGURE 7 | Effects of VP on L-type Ca ${ }^{2+}$ current ( $\left./ \mathrm{Ca}, \mathrm{L}\right)$ and non-selective cation current (/NS) in $\mathrm{GH}_{3}$ cells. In this set of experiments, we bathed cells in normal Tyrode's solution containing $1.8 \mathrm{mM} \mathrm{CaCl}_{2}, 1 \mu \mathrm{M} \mathrm{TTX}$, and $10 \mathrm{mM}$ TEA, and the pipette used was filled with $\mathrm{Cs}^{+}$-containing solution. (A) Original I/Ca,L traces elicited by membrane depolarization from -50 to $0 \mathrm{mV}$ [indicated in the upper part of (A)]. a: control; b: $1 \mu \mathrm{M}$ VP; c: $3 \mu \mathrm{M}$ VP. Panels (B) and (C) depict summarized bar graphs showing the effect of VP on the peak amplitude of $I_{\mathrm{Ca}, \mathrm{L}}$ and the slow component of inactivation time constant $\left(\tau_{\text {inact(s) }}\right)$ for $I_{\mathrm{Ca}, \mathrm{L}}$, respectively $(\mathrm{mean} \pm \mathrm{SEM}$; $n=12$ for each bar). (D) Change in the amplitude of / NS obtained in the presence of VP and VP plus illumination. The examined cell was held at the level of $-50 \mathrm{mV}$. The horizontal bar indicates addition of $3 \mu \mathrm{M}$ VP or illumination with light intensity of $5.5 \mathrm{~mW} / \mathrm{cm}^{2}$. ${ }^{*}$ Significantly different from control $(P<0.01)$.

anti-neoplastic effects of this compound and its stimulatory actions on $I_{\mathrm{K}(\mathrm{Ca})}$, before it passes through the membrane (Marks et al., 2000).
By using rose bengal, a natural polyphenolic compound known to be another type of photosensitizer, previous studies have demonstrated that this compound challenged with or 


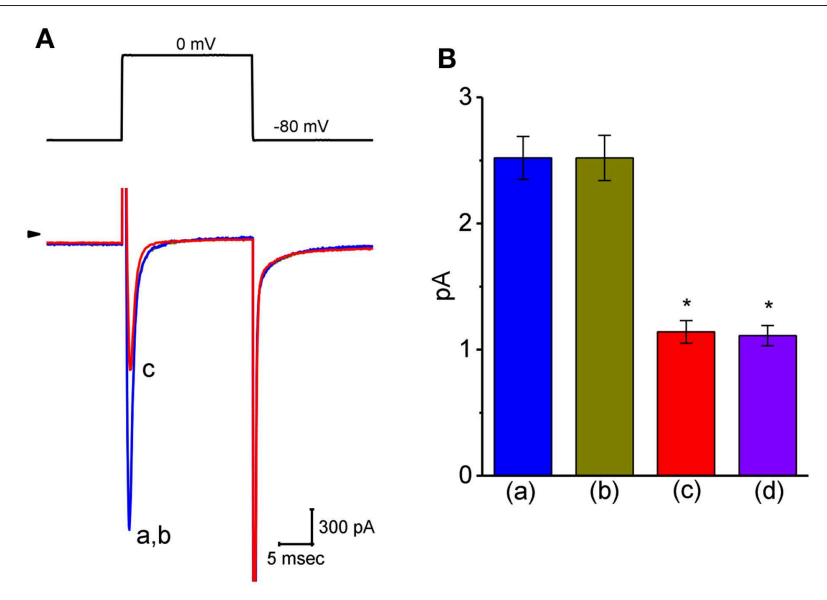

FIGURE 8 | Effect of VP on voltage-gated $\mathrm{Na}^{+}$current $\left(/_{\mathrm{Na}}\right)$ in $\mathrm{GH}_{3}$ cells. The whole-cell current recordings made in this set of experiments were conducted in cells bathed in $\mathrm{Ca}^{2+}$-free Tyrode's solution containing $10 \mathrm{mM}$ TEA and $0.5 \mathrm{mM} \mathrm{CdCl}_{2}$, and the recording pipette was filled with $\mathrm{Cs}^{+}$-containing solution. (A) Original / $\mathrm{Na}$ traces elicited by rapid membrane depolarization. The voltage protocol used is indicated in the upper part and arrowhead refers to the zero-current level. a: control; b: $3 \mu \mathrm{M}$ VP; c: $3 \mu \mathrm{M}$ VP plus $3 \mu \mathrm{M}$ A-803467. (B) Summary bar graph of the effect of VP, VP plus A-803467, and VP plus A-887826 on the peak amplitude of $/ \mathrm{Na}$ (mean $\pm \mathrm{SEM} ; n=11$ for each bar). The peak $/ \mathrm{Na}$ amplitude was measured at the beginning of short depolarizing pulse from a holding potential of $-80 \mathrm{mV}$. *Significantly different from control $(P<0.05)$.

without photosensitization was able to modify membrane ionic current in $\mathrm{GH}_{3}$ cells along with mild damage on cell growth, although these cells were described to be relatively more resistant to photosensitized modification than other type of cells (Tarr et al., 1994; Valenzeno and Tarr, 1998, 2001). Similarly, findings from this study extended the observations and showed that VP was capable of stimulating $I_{\mathrm{K}(\mathrm{Ca})}$ in a concentration-dependent manner in $\mathrm{GH}_{3}$ cells. The illumination of VP could induce a non-selective cation current (Tarr et al., 1994), which appeared to be associated with the production of reactive oxygen species, and, in turn, increase the amplitude of $I_{\mathrm{K}(\mathrm{Ca})}$ further in $\mathrm{GH}_{3}$ cells (Valenzeno and Tarr, 1998; DeRosa and Crutchley, 2002). To what extent VP with or without illumination either modifies membrane potential or senses the photochemical modification remains to be further studied. It is also interesting to examine whether there are any other molecular target(s) which can regulate the VP-induced currents.

An earlier study has notably reported the capability of VP to dissipate mitochondrial inner transmembrane potential, hence decreasing the production of intracellular ATP (Belzacq et al., 2001). The pipette solution used in our whole-cell experiments contained 3 mM ATP; in particular, the amount of intracellular ATP is sufficient to fully suppress the activity of ATP-dependent $\mathrm{K}^{+}\left(\mathrm{K}_{\mathrm{ATP}}\right)$ channels (Wu et al., 2000). Furthermore, VP-induced increase of outward currents observed in $\mathrm{GH}_{3}$ cells was unable to be reversed by subsequent application of either tolbutamide, a blocker of $\mathrm{K}_{\mathrm{ATP}}$ channels, or TRAM-39, an inhibitor of IK $\mathrm{Ca}$ channels (Huang et al., 2015; Chen P. C. et al., 2018; Chen T. S. et al., 2018; Liu et al., 2019a). As such, VP-induced increase in $\mathrm{K}^{+}$ outward currents conceivably is not associated with the activation of $\mathrm{K}_{\mathrm{ATP}}$ or $\mathrm{IK}_{\mathrm{Ca}}$ channels. Alternatively, in continued presence of VP, the ability of subsequent addition of dithiothreitol, a sulfhydryl reducing agent, to reverse VP-stimulated $I_{\mathrm{K}(\mathrm{Ca})}$ seems to lend credence to suggest a possible link to VP-induced production of free oxygen species (DeRosa and Crutchley, 2002; Morishita et al., 2016; Baskaran et al., 2018; Eales et al., 2018; Kim et al., 2018).

In our cell-attached current recordings, addition of VP into the bath increased the activity of $\mathrm{BK}_{\mathrm{Ca}}$ channels significantly with no clear change in the single-channel conductance. These results can be stated as meaning that VP-stimulated channel activity results largely from the availability of intracellular $\mathrm{Ca}^{2+}$, despite inability of the VP molecules to act within the $\mathrm{BK}_{\mathrm{Ca}^{-}}$ channel's central pore. However, VP-mediated activation of $\mathrm{BK}_{\mathrm{Ca}}$ channels found in $\mathrm{GH}_{3}$ cells actually did not depend on increased availability of intracellular $\mathrm{Ca}^{2+}$ owing to elevated $\mathrm{Ca}^{2+}$ flux through voltage-gated $\mathrm{Ca}^{2+}$ channels, given the present results showing that VP effectively suppressed the amplitude of $I_{\mathrm{Ca}, \mathrm{L}}$ in $\mathrm{GH}_{3}$ cells. Additionally, in inside-out current recordings, as VP was applied to the intracellular surface of the excised patch, little or no change in the activity of $\mathrm{BK}_{\mathrm{Ca}}$ channels was demonstrated; however, subsequent addition of GMQ or PF573228, known to stimulate $\mathrm{BK}_{\mathrm{Ca}}$ channels, was effective at raising the channel open probability (So et al., 2011, 2018). Notably, it has been also demonstrated that $\mathrm{BK}_{\mathrm{Ca}}$ channels are functionally expressed in either retinal pigment epithelial cells, vascular endothelial cells, or amniotic fluid-derived stem cells (Li et al., 2000; SchmidtErfurth and Hasan, 2000; Sheu et al., 2005; Hua et al., 2014; $\mathrm{Hu}$ et al., 2015; Liu et al., 2015, 2018, 2019a,b). Taking this into account, to what extent VP-induced changes in $\mathrm{BK}_{\mathrm{Ca}^{-}}$ channel activity existing in these cells are intimately connected with its actions on sensory retina or pituitary adenoma during photodynamic therapy (Marks et al., 2000; Rahimipour et al., 2003; Rosenblatt et al., 2005; Hu et al., 2015; Nemes et al., 2016; Liu et al., 2018; Min et al., 2018; Iacono et al., 2019) remains to be imperatively investigated.

As being administrated, the VP molecules need to enter into cytosol or even nucleus, before being destined for having an interaction with YAP-TEAD complex (Brodowska et al., 2014; Feng et al., 2016; Gibault et al., 2016, 2017; Abe et al., 2018; Qin et al., 2019); hence, they must pass through surface membrane before entering the cell interior. From findings in this study, it is therefore tempting to speculate that the perturbations on membrane ion currents caused by VP would be required to precede its subsequent actions through suppression of YAPTEAD complex. Moreover, another important determinants needed to be considered are the VP dose and the intensity of illumination, since the stimulatory effect of VP on $I_{\mathrm{K}(\mathrm{Ca})}$ could be highly related to generation of reactive oxygen species (Morishita et al., 2016; Baskaran et al., 2018; Eales et al., 2018; Kim et al., 2018). The sensitization sites for the modification caused by the VP molecules are thought to be probably at an intramembranous location near the inner surface. Upon cell exposure to VP particularly along with long-term light exposure, the reactive oxygen species would be excessively produced, and resultant byproducts of oxidative metabolism can then interact 

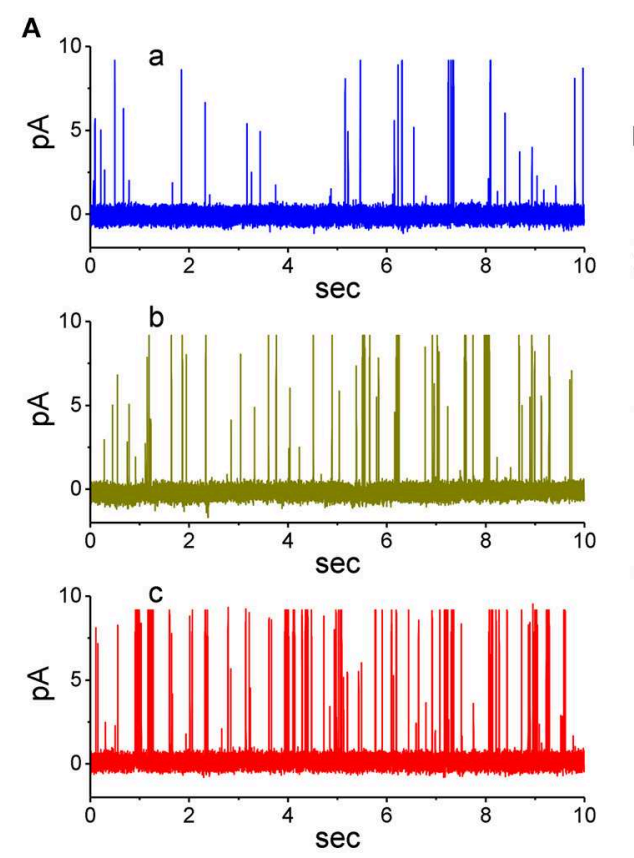

B

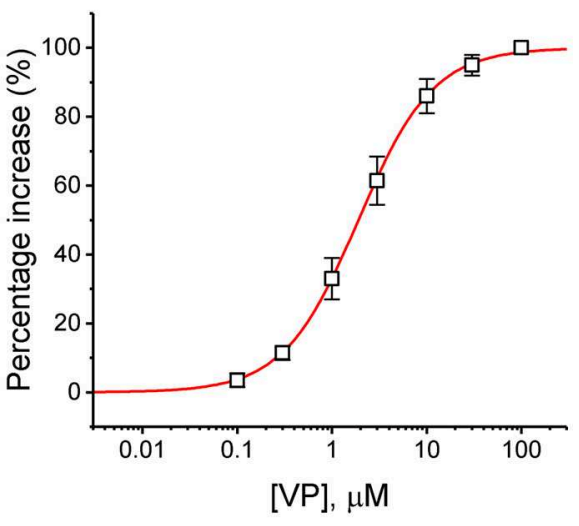

FIGURE 9 | Stimulatory effect of VP on $\mathrm{BK}_{\mathrm{Ca}}$-channel activity recorded from human 13-06-MG glioma cells. In this series of experiments, we bathed cells in normal Tyrode's solution and filled the recording pipette by using high $\mathrm{K}^{+}$-containing solution. (A) Representative $\mathrm{BK}_{\mathrm{Ca}}$-channel currents taken under a holding potential of $+60 \mathrm{mV}$ relative to the bath. a: control; b: $1 \mu \mathrm{M}$ VP; c: $3 \mu \mathrm{M}$ VP. (B) Concentration-dependent relationship of VP effect on the probability of $\mathrm{BK}_{\mathrm{Ca}}{ }^{-c h a n n e l}$ openings in 13-06-MG cells (mean $\pm \mathrm{SEM} ; n=11$ for each point). The examined cell was held at $+60 \mathrm{mV}$ relative to the bath, and the channel open probability during the exposure to $100 \mu \mathrm{M}$ VP was taken to be $100 \%$. The smooth line represents the least-squares fit of the data points to the sigmoidal Hill equation as described in Materials and Methods. The values of $\mathrm{EC}_{50}$, Hill coefficient, and maximal percentage increase of channel activity were estimated to be $1.9 \mu \mathrm{M}, 1.1$, and $100 \%$, respectively.

with membrane phospholipids and proteins that constitute ion transport pathways such as $\mathrm{BK}_{\mathrm{Ca}}$ channels. Lastly, It will be worthy of being investigated regarding to what extent VPmediated modifications on membrane ion channels reported herein is closely linked to the inhibition of VAP-TEAD complex followed by changes in proliferation or differentiation of different types of neoplastic or stem cells, given that the fact that such photosensitizers as sensitized photochemical modification in an array of tumors, including pituitary tumors and gliomas, have been widely utilized (Marks et al., 2000; Brown et al., 2004; Solban et al., 2006; Triesscheijn et al., 2006; Cole et al., 2008; Brodowska et al., 2014; Valero et al., 2015; Morishita et al., 2016; Nemes et al., 2016; Chen and Hu, 2017; Baskaran et al., 2018; Liao et al., 2018; Mulder et al., 2018; Chen et al., 2019; Li et al., 2019; Pellosi et al., 2019; Qin et al., 2019; Zhang et al., 2019). Alternatively, the efficacy of VP in inhibiting YAP/TEAD interaction was currently noted to remain debated (Lui et al., 2019). Regardless of the detailed mechanism of VP actions, it is pertinent to point out that VP-induced modifications on membrane ion channels shown herein should not be ignored and is conceivably responsible for effecting its therapeutic or adverse actions (Marks et al., 2000; Abe et al., 2018; Min et al., 2018; Iacono et al., 2019 Isildak et al., 2019).

\section{DATA AVAILABILITY}

The raw data supporting the conclusions of this manuscript will be made available by the authors, without undue reservation, to any qualified researcher.

\section{AUTHOR CONTRIBUTIONS}

All authors listed have made a substantial, direct and intellectual contribution to the work, and approved it for publication.

\section{ACKNOWLEDGMENTS}

This study that led to the composition of this manuscript was supported in part by National Cheng Kung University (D106-35A13, D107-F2519, and NCKUH-10709001 to S-NW), Tainan City, Taiwan. The authors would like to acknowledge the technical assistance of Kaisen Lee for helping earlier work in this study. S-NW received a Talent Award for the Outstanding Researchers from Ministry of Education, Taiwan. 


\section{REFERENCES}

Abe, T., Amaike, Y., Shizu, R., Takahashi, M., Kano, M., Hosaka, T., et al. (2018). Role of YAP activation in nuclear receptor CAR-mediated proliferation of mouse hepatocytes. Toxicol. Sci. 165, 408-419. doi: 10.1093/toxsci/k fy 149

AlAmri, M., Kadri, H., Alderwick, L. J., Jeeves, M., and Mehellou, Y. (2018). The photosensitizing clinical agent verteporfin is an inhibitor of SPAK and OSR1 kinases. Chembiochem 4, 2072-2080. doi: 10.1002/cbic.2018 00272

Al-Moujahed, A., Brodowska, K., Stryjewski, T. P., Efstathiou, N. E., Vasilikos, I., Cichy, J., et al. (2017). Verteporfin inhibits growth of human glioma in vitro without light activation. Sci. Rep.7:7602. doi: 10.1038/s41598-017-07632-8

Baskaran, R., Lee, J., and Yang, S. G. (2018). Clinical development of photodynamic agents and therapeutic applications. Biomater. Res. 22:25. doi: 10.1186/s40824-018-0140-z

Belzacq, A. S., Jacotot, E., Vieira, H. L., Mistro, D., Granville, D. J., Xie, Z., et al. (2001). Apoptosis induction by the photosensitizer verteporfin: identification of mitochondrial adenine nucleotide translocator as a critical target. Cancer Res. $61,1260-1264$

Brodowska, K., Al-Moujahad, A., Marmalidou, A., Meyer, Z. U., Horste, M., Cichy, J., et al. (2014). The clinically used photosensitizer verteporfin (VP) inhibits YAP-TEAD and human retinoblastoma cell growth in vitro without light activation. Exp. Eye Res. 124, 67-73. doi: 10.1016/j.exer.2014. 04.011

Brown, S. B., Brown, E. A., and Walker, I. (2004). The present and further role of photodynamic therapy in cancer treatment. Lancet Oncol. 5, 497-508. doi: 10.1016/s1470-2045(04)01529-3

Chen, P. C., Ruan, J. S., and Wu, S. N. (2018). Evidence of decreased activity in intermediate-conductance calcium-activated potassium channels during retinoic acid-induced differentiation in motor neuron-like NSC-34 cells. Cell. Physiol. Biochem. 48, 2374-2388. doi: 10.1159/0004 92653

Chen, T. S., Lai, M. C., Hung, T. Y., Lin, K. M., Huang, C. W., and Wu, S. N. (2018). Pioglitazone, a PPAR- $\gamma$ activator, stimulates $B K_{C a}$ but suppresses $I K_{M}$ in hippocampal neurons. Front. Pharmacol. 9:977. doi: 10.3389/fphar.2018. 00977

Chen, Y., and $\mathrm{Hu}$, Y. (2017). Photodynamic therapy for an iris metastasis from pulmonary adenocarcinoma. Photodiagn. Photodyn. Ther. 20, 246-247. doi: 10.1016/j.pdpdt.2017.10.011

Chen, Y. A., Lu, C. Y., Cheng, T. Y., Pan, S. H., Chen, H. F., and Chang, N. S. (2019). WW domain-containing proteins YAP and TAZ in the Hippo pathway as key regulators in stemness maintenance, tissue homeostasis, and tumorigenesis. Front. Oncol. 9:60. doi: 10.3389/fonc.2019.00060

Cole, C. D., Liu, J. K., Sheng, X., Chin, S. S., Schmidt, M. H., Weiss, M. H., et al. (2008). Hypericin-mediated photodynamic therapy of pituitary tumors: preclinical study in a $\mathrm{GH}_{4} \mathrm{C}_{1}$ rat tumor model. J. Neurooncol. 87, 255-261. doi: $10.1007 / \mathrm{s} 11060-007-9514-0$

Deng, W., Chen, W., Clement, S., Guller, A., Zhao, Z., Engel, A., et al. (2018). Controlled gene and drug release from a liposomal delivery platform triggered by X-ray radiation. Nat. Commun. 9:2713. doi: 10.1038/s41467-01805118-3

DeRosa, M. C., and Crutchley, R. J. (2002). Photosensitized singlet oxygen and its applications. Coord. Chem. Rev. 233-234, 351-371. doi: $10.1016 /$ S0010-8545(02)00034-6

Eales, K. L., Wilkinson, E. A., Cruickshank, G., Tucker, J. H. R., and Tennant, D. A. (2018). Verteporfin selectively kills hypoxic glioma cells through ironbinding and increased production of reactive oxygen species. Sci. Rep. 8:14358. doi: 10.1038/s41598-018-32727-1

Eskelin, S., Tommila, P., Palosaari, T., and Kivelä, T. (2008). Photodynamic therapy with verteporfin to induce regression of aggressive retinal astrocytomas. Acta Ophthalmol. 86, 794-799. doi: 10.1111/j.1755-3768.2007. 01151.x

Faustino, M. A., Neves, M. G., Vicente, M. G., Cavaleiro, J. A., Neumann, M., Brauer, H. D., et al. (1997). Meso-tetraphenylpoorphyrin dimer derivative as a potential photosensitizer in photodynamic therapy. Photochem. Photobiol. $66,405-412$.
Feng, J., Gou, J., Jia, J., Yi, T., Cui, T., and Li, Z. (2016). Verteporfin, a suppressor of YAP-TEAD complex, presents promising antitumor properties on ovarian cancer. Onco. Targets Ther. 9, 5371-5381. doi: 10.2147/OTT.S1 09979

Ghazai, B., Machacek, M., Shalaby, M. A., Novakova, V., Zimcik, P., and Makhseed, S. (2017). Phthalocyanines and tetrapyrazinoporphyrazines with two cationic donuts: high photodynamic activity as a result of rigid spatial arrangement of peripheral substituents. J. Med. Chem. 60, 6060-6076. doi: 10.1021 acs.jmedchem.7b00272

Gibault, F., Bailly, F., Corvaisier, M., Coevoet, M., Huet, G., Melnyk, P., et al. (2017). Molecular features of the YAP inhibitor verteporfin: synthesis of hexasubstituted dipyrrins as potential inhibitors of YAP/TAZ, the downstream effects of the Hippo Pathway. ChemMedChem 12, 954-961. doi: $10.1002 / \mathrm{cmdc} .201700063$

Gibault, F., Corvaisier, M., Bailly, F., Huet, G., Melnyk, P., and Cotelle, P. (2016). Non-photoinduced biological properties of verteporfin. Curr. Med. Chem. 23, 1171-1184. doi: 10.2174/09298673236661603161 25048

Hu, Y., Chen, Y., and Chen, L. (2015). Half-dosage and bolus injection photodynamic therapy for symptomatic circumscribed choroidal hemangioma: a case report. Photodiagn. Photodyn. Ther. 12, 526-529. doi: 10.1016/j.pdpdt.2015.05.005

Hua, R., Liu, L., Li, C., and Chen, L. (2014).Evaluation of the effects of photodynamic therapy on chronic central serous chorioretinopathy based on the mean choroidal thickness and the lumen area of abnormal choroidal vessels. Photodiagn. Phododyn. Ther. 11, 519-525. doi: 10.1016/j.pdpdt.2014. 07.005

Huang, M. H., Huang, Y. M., and Wu, S. N. (2015). The inhibition by oxaliplatin, a platinum-based anti-neoplastic agent, of the activity of intermediateconductance $\mathrm{Ca}^{2+}$-activated $\mathrm{K}^{+}$channels in human glioma cells. Cell. Physiol. Biochem. 37, 1390-1406. doi: 10.1159/000430404

Iacono, P., Toto, L., Eliana, C., Varano, M., and Parravano, M. C. (2019). Pharmacotherapy of central serous chorioretinopathy: review of the current treatments. Curr. Pharm. Des. 24, 4864-4873. doi: 10.2174/1381612825666190123165914

Isildak, H., Schwartz, S. G., and Flynn, H. W. (2019). Pharmacotherapy of myopic choroidal neovascularization. Curr. Pharm. Des. 24, 4853-4859. doi: $10.2174 / 1381612825666190124102641$

Kandoussi, I., Lakhlili, W., Taoufik, J., and Ibrahimi, A. (2017). Docking analysis of verteporfin with YAP WW domain. Bioinformation 13, 237-240. doi: $10.6026 / 97320630013237$

Karacorlu, M., Karacorlu, S., and Ozdemir, H. (2004). Nonarteritic anterior ischemic optic neuropathy after photodynamic therapy for choroidal neovascularization. Jpn. J. Ophthalmol. 48, 424-426. doi: 10.1007/s10384-004-0078-7

Kim, T. W., Moon, J. W., and Yu, H. G. (2018). N-acetylcysteine protects against chorioretinal damage induced by photodynamic therapy for experimental choroidal neovascularization in a rat model. Phtodiagn. Photodyn. Ther. 23, 12-17. doi: 10.1016/j.pdpdt.2018.04.006

Konstantinou, E. K., Notomi, S., Kosmidou, C., Brodowska, K., Al-Moujahed, A., Nicolaou, F., et al. (2017). Verteporfin-induced formation of protein cross-linked oligomers and high molecular weight complexes is mediated by light and leads to cell toxicity. Sci. Rep. 7:46581. doi: 10.1038/srep 46581

Li, H. F., Chen, S. A., and Wu, S. N. (2000). Evidence for the stimulatory effect of resveratrol on $\mathrm{Ca}^{2+}$-activated $\mathrm{K}^{+}$current in vascular endothelial cells. Cardiovasc. Res. 45, 1035-1045. doi: 10.1016/S0008-6363(99)00397-1

Li, Y., Wang, S., Wei, X., Zhang, S., Song, Z., Chen, X., et al. (2019). Role of inhibitor of yes-associated protein 1 in triple-negative breast cancer with taxol-based chemoresistance. Cancer Sci. 110, 561-567. doi: 10.1111/cas.13888

Liao, T., Wei, W. J., Wen, D., Hu, J. Q., Wang, Y., Ma, B., et al. (2018). Verteporfin inhibits papillary thyroid cancer cells proliferation and cell cycle through ERK1/2 signaling pathway. J. Cancer. 9, 1329-1336. doi: 10.7150/jca.21915

Lin, J., Gu, Y., Du, R., Deng, M., Lu, Y., and Ding, Y. (2014). Detection of EGFR mutation in supernatant, cell pellets of pleural effusion and tumor tissues from non-small cell lung cancer patients by high resolution melting analysis and sequencing. Int. J. Clin. Exp. Pathol. 7, 8813-8822. 
Lin, M. W., Yang, S. R., Huang, M. H., and Wu, S. N. (2004). Stimulatory actions of caffeic acid phenethyl ester, a known inhibitor of NF-KB activation, on $\mathrm{Ca}^{2+}$ activated $\mathrm{K}^{+}$current in pituitary $\mathrm{GH}_{3}$ cells. J. Biol. Chem. 279, 26885-26892. doi: 10.1074/jbc.M400356200

Liu, C. C., Huang, Y. M., Wu, S. N., and Sze, C. I. (2015). Correlation of mesenchymal differentiation and ion-channel activity in radiation-induced resistant human glioblastoma cell line. FASEB J. 29:1. Available online at: https://www.fasebj.org/doi/abs/10.1096/fasebj.29.1_supplement.844.17

Liu, L., Hu, C., Chen, L., and Hu, Y. (2018). Photodynamic therapy for symptomatic circumscribed choroidal hemangioma in 22 Chinese patients: a retrospective study. Photodiagn. Photodyn. Ther. 24, 372-376. doi: 10.1016/j.pdpdt.2018.10.019

Liu, Y. W., Fang, Y. H., Su, C. T., Hwang, S. M., Liu, P. Y., and Wu, S. N. (2019a). The biochemical and electrophysiological profiles of amniotic fluidderived stem cells following Wnt signaling modulation cardiac differentiation. Cell Death Discov. 5:59. doi: 10.1038/s41420-019-0143-0

Liu, Y. Y., Hsiao, H. T., Wang, J. C., Liu, Y. C., and Wu, S. N. (2019b). Parecoxib, a selective blocker of cyclooxygenase-2, directly inhibits neuronal delayedrectifier $\mathrm{K}^{+}$current, M-type $\mathrm{K}^{+}$current and $\mathrm{Na}^{+}$current. Eur. J. Pharmacol. 844, 95-101. doi: 10.1016/j.ejphar.2018.12.005

Lui, J. W., Xiao, S., Ogomori, K., Hammarstedt, J. E., Little, E. C., and Lang, D. (2019). The efficacy of verteporfin as a therapeutic option in pre-clinical models of melanoma. J. Cancer. 10, 1-10. doi: 10.7150/jca.27472

Marks, P. V., Belchetz, P. E., Saxena, A., Igbaseimokumo, U., Thomson, S., Nelson, M., et al. (2000). Effect of photodynamic therapy on recurrent pituitary adenomas: clinical phase I/II trial-an early report. Br. J. Neurosurg. 14, 317-325. doi: 10.1080/026886900417298

Min, J. Y., Lv, Y., Mao, L., Gong, Y. Y., Gu, Q., and Wei, F. (2018). A rodent model of anterior ischemic optic neuropathy (AION) based on laser photoactivation of verteporfin. BMC Ophthalmol. 18:304. doi: 10.1186/s12886-018-0937-5

Morishita, T., Hayakawa, F., Sugimoto, K., Iwase, M., Yamamoto, H., Hirano, D., et al. (2016). The photosensitizer verteporfin has lightindependent anti-leukemic activity for Ph-positive acute lymphoblastic leukemia and synergistically works with dasatinib. Oncotarget 7, 56241-56252. doi: 10.18632 /oncotarget.11025

Mulder, C. L., Eijkenboom, L. L., Beerendonk, C. C. M., Braat, D. D. M., and Peek, R. (2018). Enhancing the safety of ovarian cortex autotransplantation: cancer cells are purged completely from human ovarian tissue fragments by pharmacological inhibition of YAP/TAZ oncoproteins. Hum. Reprod. 34, 506-518. doi: 10.1093/humrep/dey384

Nemes, A., Fortmann, T., Poeschke, S., Greve, B., Prevedello, D., Santacroce, A., et al. (2016). 5-ALA fluorescence in native pituitary adenoma cell lines: resection control and basis for photodynamic therapy (PDT)? PLOS ONE 11:e0161364. doi: 10.1371/journal.pone.0161364

Pellosi, D. S., Paula, L. B., de Melo, M. T., and Tedesco, A. C. (2019). Targeted and synergic glioblastoma treatment: multifunctional nanoparticle delivering verteporfin as adjuvant therapy for temozolomide chemotherapy. Mol. Pharm. 16, 1009-1024. doi: 10.1021/acs.molpharmaceut. $8 \mathrm{~b} 01001$

Qin, X., Li, J., Sun, J., Liu, L., Chen, D., and Liu, Y. (2019). Low shear stress induces ERK nuclear localization and YAP activation to control the proliferation of breast cancer cells. Biochem. Biophys. Res. Commun. 510, 219-223. doi: 10.1016/j.bbrc.2019.01.065

Rahimipour, S., Ben-Aroya, N., Ziv, K., Chen, A., Fridkin, M., and Koch, Y. (2003). Receptor-mediated targeting of a photosensitizer by its conjugation to gonadotropin-releasing hormone analogues. J. Med. Chem. 46, 3965-3974. doi: $10.1021 / \mathrm{jm} 020535 \mathrm{y}$

Renno, R. Z., Terada, Y., Haddadin, M. J., Michaud, N. A., Gragoudas, E. S., and Miller, J. W. (2004). Selective photodynamic therapy by targeted verteporfin delivery to experimental choroidal neovascularization mediated by a homing peptide to vascular endothelial growth factor receptor-2. Arch. Ophthalmol. 122, 1002-1011. doi: 10.1001/archopht.122.7.1002

Rosenblatt, B. J., Shah, G. K., and Blinder, K. (2005). Photodynamic therapy with verteporfin for pericapillary choroidal neovascularization. Retina 25, 33-37.

Rush, A. M., and Cummins, T. R. (2007). Painful research: identification of a smallmolecule inhibitor that selectively targets $\mathrm{Na}_{\mathrm{V}} 1.8$ sodium channels. Mol. Interv. 7, 192-195. doi: 10.1124/mi.7.4.4
Sankaranarayanan, S., and Simasko, S. M. (1996). Characterization of an Mlike current modulated by thyrotropin-releasing hormone in normal rat lactotrophs. J. Neurosci. 16, 1668-1678.

Schmidt-Erfurth, U., and Hasan, T. (2000). Mechanisms of action of photodynamic therapy with verteporfin for the treatment of age-related macular degeneration. Surv. Ophthalmol. 45, 195-214. doi: 10.1016/S0039-6257(00)00158-2

Sheu, S. J., Wu, S. N., and Hu, D. N. (2005). Stretch-stimulated activity of large conductance calcium-activated potassium channels in human retinal pigment epithelial cells. J. Ocul. Pharmacol. Ther. 21, 429-435. doi: 10.1089/jop.2005.21.429

So, E. C., Foo, N. P., Ko, S. Y., and Wu, S. N. (2019). Bisoprolol, known to be a selective $\beta_{1}$-receptor antagonist, differentially but directly suppresses $I_{K(M)}$ and $\mathrm{I}_{\mathrm{K}(\mathrm{erg})}$ in pituitary cells and hippocampal neurons. Int. J. Mol. Sci. 20:657. doi: 10.3390/ijms20030657

So, E. C., Wang, Y., Yang, L. Q., So, K. H., Lo, Y. C., and Wu, S. N. (2018). Multiple regulatory actions of 2-guanidine-4-methylquinazoline (GMQ), an agonist of acid-sensing ion channel type-3, on ionic currents in pituitary $\mathrm{GH}_{3}$ cells and in olfactory sensory (Rolf B1.T) neurons. Biochem. Pharmacol. 151, 79-88. doi: 10.1016/j.bcp.2018.02.027

So, E. C., Wu, K. C., Liang, C. H., Chen, J. Y., and Wu, S. N. (2011). Evidence for activation of $\mathrm{BK}_{\mathrm{Ca}}$ channels by a known inhibitor of focal adhesion kinase, PF573228. Life Sci. 89, 691-701. doi: 10.1016/j.lfs.2011. 08.013

Solban, N., Rizvi, I., and Hasan, T. (2006). Targeted photodynamic therapy. Lasers Surg. Med. 38, 522-531. doi: 10.1002/lsm.20345

Stojilkovic, S. S., Tabak, J., and Bertram, R. (2010). Ion channels and signaling in the pituitary gland. Endoc. Rev. 31, 845-915. doi: 10.1210/er.20100005

Tarr, M., Arriaga, E., Goertz, K. K., and Valenzeno, D. P. (1994). Properties of cardiac $\mathrm{I}_{\text {leak }}$ induced by photosensitizer-generated reactive oxygen. Free Radic. Biol. Med. 16, 477-484.

Tekrony, A. D., Kelly, N. M., Fage, B. A., and Cramb, D. T. (2011). Photobleaching kinetics of verteporfin and lemuteporfin in cells and optically trapped multilamellar vesicles using two-photon excitation. Photochem. Photobiol. 87, 853-861. doi: 10.1111/j.1751-1097.2011. 00933.x

Triesscheijn, M., Baas, P., Schellens, J. H., and Stewart, F. A. (2006) Photodynamic therapy in oncology. Oncologist 11, 1034-1044. doi: 10.1634/theoncologist.11-9-1034

Valenzeno, D. P., and Tarr, M. (1998). $\mathrm{GH}_{3}$ cells, ionic currents and cell killing: photomodification sensitized by Rose Bengal. Photochem. Photobiol. $68,519-526$.

Valenzeno, D. P., and Tarr, M. (2001). Calcium as a modulator of photosensitized killing of $\mathrm{H} 9 \mathrm{c} 2$ cardiac cells. Phtochem. Photobiol. $74, \quad 605-610$. doi: $\quad 10.1562 / 0031-8655(2001) 074<0605:$ caamop $>2$. $0 . \operatorname{co} ; 2$

Valero, V. III., Pawlik, T. M., and Anders, R. A. (2015). Emerging role of Hpo signaling and YAP in hepatocellular carcinoma. J. Hepatocell Carcinoma 2, 69-78. doi: 10.2147/JHC.S48505

Wu, S. N., Chern, J. H., Shen, S., Chen, H. H., Hsu, Y. T., Lee, C. C., et al. (2017). Stimulatory actions of a novel thiourea derivative on largeconductance, calcium-activated potassium channels. J. Cell. Physiol. 232, 3409-3421. doi: $10.1002 /$ jcp. 25788

Wu, S. N., Chiang, H. T., Shen, A. Y., and Lo, Y. K. (2003). Differential effects of quercetin, a natural polyphenolic flavonoid on L-type calcium current in pituitary tumor $\left(\mathrm{GH}_{3}\right)$ cells and neuronal NG108-15 cells. J. Cell. Physiol. 195, 298-308. doi: $10.1002 /$ jcp. 10244

Wu, S. N., Li, H. F., and Chiang, H. T. (2000). Characterization of ATP-sensitive potassium channels functionally expressed in pituitary $\mathrm{GH}_{3}$ cells. J. Membr. Biol. 178, 205-214. doi: 10.1007/s002320010028

Wu, S. N., Li, H. F., and Jan, C. R. (1998a). Regulation of $\mathrm{Ca}^{2+}$-activated nonselective cationic currents in rat pituitary $\mathrm{GH}_{3}$ cells: involvement in Ltype $\mathrm{Ca}^{2+}$ current. Brain Res. 812, 133-141. doi: 10.1016/s0006-8993(98) 00964-0

Wu, S. N., Li, H. F., Jan, C. R., Chen, I. J., and Lo, Y. C. (1998b). Selective block by glyceryl nonivamide of inwardly rectifying $\mathrm{K}^{+}$current in rat anterior 
pituitary $\mathrm{GH}_{3}$ cells. Life Sci. 63, PL281-PL288. doi: 10.1016/s0024-3205(98) 00447-0

Zhang, Q., Guo, Y., Yu, H., Tang, Y., Yuan, Y., Jiang, Y., et al. (2019). Receptor activity-modifying protein 1 regulates the phenotypic expression of BMSCs via the Hippo/Yap pathway. J. Cell. Physiol. 234, 13969-13976. doi: $10.1002 /$ jcp. 28082

Zhang, X. F., Shieh, C. C., Chapman, M. L., Matulenko, M. A., Hakeem, A. H., Atkinson, R. N., et al. (2010). A-887826 is a structurally novel, potent and voltage-dependent $\mathrm{Nav} 1.8$ sodium channel blocker that attenuates neuropathic tactile allodynia in rats. Neuropharmacology 59, 201-207. doi: 10.1016/j.neuropharm.2010.05.009

Zhou, X., Chen, B., Hoopes, P. J., Hasan, T., and Pogue, B. W. (2006). Tumor vascular area correlates with photosensitizer uptake: analysis of verteporfin microvascular delivery in the Dunning rat prostate tumor. Photochem. Photobiol. 82, 1348-1357. doi: 10.1562/2006-03-25-ra-858

Conflict of Interest Statement: The authors declare that the research was conducted in the absence of any commercial or financial relationships that could be construed as a potential conflict of interest.

Copyright (c) 2019 Huang, Liu and Wu. This is an open-access article distributed under the terms of the Creative Commons Attribution License (CC BY). The use, distribution or reproduction in other forums is permitted, provided the original author(s) and the copyright owner(s) are credited and that the original publication in this journal is cited, in accordance with accepted academic practice. No use, distribution or reproduction is permitted which does not comply with these terms. 